\title{
The Impact of the 2017 Tax Act on Certain Personal Injury Plaintiffs
}

\author{
Gregg Polsky \\ Francis Shackelford Distinguished Professor in Taxation Law University of Georgia School of Law, \\ gregg.polsky@uga.edu
}

University of Georgia School of Law

Research Paper Series

Paper No. 2020-30

P bepress

\section{Repository Citation}

Gregg Polsky, The Impact of the 2017 Tax Act on Certain Personal Injury Plaintiffs , 12 Colum. J. Tax L. 27 (2020),

Available at: https://digitalcommons.law.uga.edu/fac_artchop/1402

This Article is brought to you for free and open access by the Faculty Scholarship at Digital Commons @ University of Georgia School of Law. It has been accepted for inclusion in Scholarly Works by an authorized administrator of Digital Commons @ University of Georgia School of Law. Please share how you have benefited from this access For more information, please contact tstriepe@uga.edu. 


\title{
THE IMPACT OF THE 2017 TAX ACT ON CERTAIN PERSONAL INJURY PLAINTIFFS
}

\author{
Gregg Polsky*
}

\begin{abstract}
The 2017 Tax Act was the most sweeping federal tax legislation in over a generation. While many of its reforms, from dramatically lowering the corporate tax rate to altering the international tax rules, have already received significant attention, comparatively little attention has been paid to the 2017 Tax Act's effects on personal injury plaintiffs. This Article explores those impacts.

The 2017 Tax Act added a new provision that indirectly affects plaintiffs who allege sexual harassment or abuse. The new provision disallows the defendants' deductions if the parties enter into a nondisclosure agreement. While targeted at defendants, the provision likely unwittingly harms plaintiffs by reducing settlement offers. The provision also suffers from a host of ambiguities that the Treasury Department and Internal Revenue Service will need to resolve.

The 2017 Tax Act also eliminated so-called miscellaneous itemized deductions. In certain types of personal injury claims, such as defamation or emotional distress, this development causes the plaintiff to be taxed on the full settlement amount even if, as is often the case, one-third or more of the settlement is paid as a contingent fee to the plaintiff's attorney. Legislative or administrative action is required to remedy this patent unfairness.
\end{abstract}

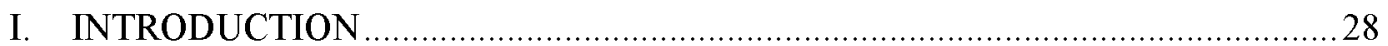

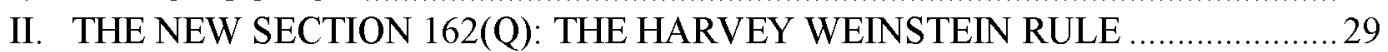

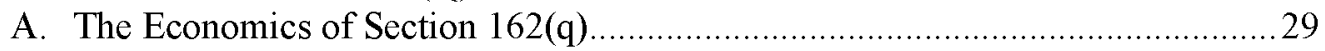

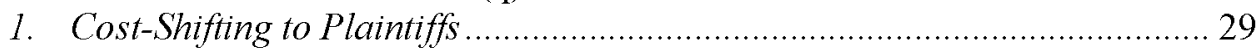

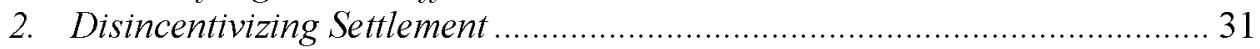

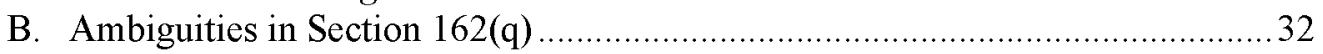

1. The Problem of Multiple Claims and Global Settlements ........................ 32

2. What Constitutes a Non-Disclosure Agreement for Section 162(q) Purposes?

3. What are "Related" Attorney's Fees?

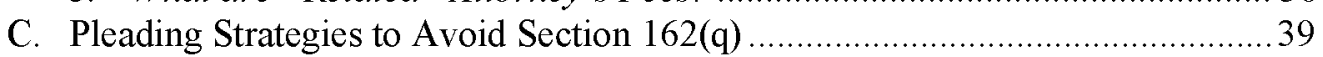

III. EXACERBATION OF THE CONTINGENT FEE TAX TRAP .......................... 40

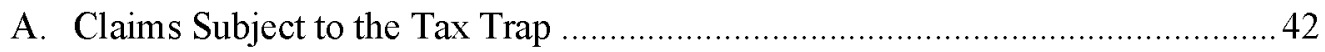

B. Tax Policy Implications .............................................................................. 44

C. Does the Form of Attorney Fee Payment Matter? ...........................................47

\footnotetext{
* Francis Shackelford Distinguished Professor in Taxation Law, University of Georgia School of Law. Thanks to Brant Hellwig and Lawrence Zelenak for comments and to Phillip Chason for research assistance. This work was supported by a grant from the American Association for Justice Robert L. Habush Endowment.
} 
D. Federal Comprehensive Legislative Solution …............................................ 48

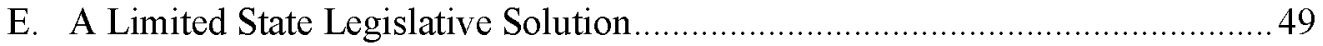

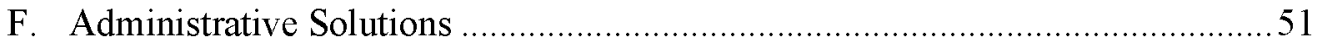

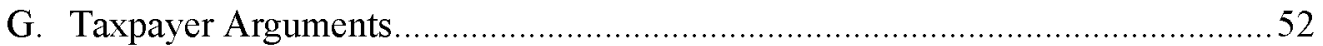

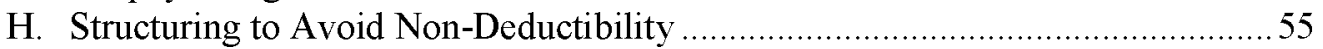

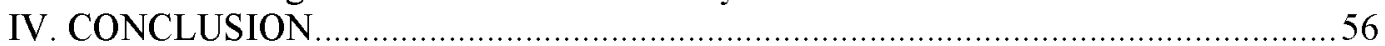

\section{INTRODUCTION}

The federal income tax legislation signed into law on December 17, 2017 (2017 Tax Act) was the most sweeping federal tax reform legislation in over thirty years, with an estimated cost of $\$ 1.5$ trillion over the ten-year budget window. ${ }^{1}$ Most significantly, the 2017 Tax Act reduced the corporate tax rate from $35 \%$ to $21 \%$, added a brand new passthrough deduction for non-corporate businesses, and dramatically reformed the international tax regime. ${ }^{2}$ While these and other headline reforms have garnered substantial attention, additional changes have remained largely unexplored, even though they may significantly affect narrow classes of taxpayers. This Article addresses the impact of the 2017 Tax Act on one of those narrow classes: certain plaintiffs in personal injury litigation.

The 2017 Tax Act added a new rule, officially section 162(q), but informally known as the Harvey Weinstein rule, that disallows tax deductions for settlements of sexual harassment or sexual abuse claims that include a nondisclosure agreement (NDA). ${ }^{3}$ This appears to be the first time that the federal tax laws have been used to discourage the use of NDAs. While surely instigated by good intentions, section 162(q) is a highly flawed tax rule for two reasons. First, because the provision operates as a tax on the "sale" of an NDA by plaintiffs to defendants and because some portion of that tax burden will likely be shifted to plaintiffs in the form of lower settlement offers, victims of sexual harassment or abuse will bear at least some brunt of the costs imposed under section $162(\mathrm{q}){ }^{4}{ }^{4}$ Second, despite its apparent simplicity, section 162(q) suffers from a host of ambiguities that will prove extremely difficult, if not impossible, for rule makers at the Treasury Department and the Internal Revenue Service (IRS) to resolve effectively.

The new tax law also disallowed so-called "miscellaneous itemized deductions." Typically, these deductions are relatively small, so taxpayers often do not miss them much. But in some personal injury cases, such as defamation suits, the plaintiff's contingent fee is classified as a miscellaneous itemized deduction. ${ }^{5}$ In such cases, the plaintiff will be taxed on the full settlement amount even though $40 \%$ or more may go to the plaintiff's attorney.

This article proceeds as follows: Part II explores the implications of the Harvey Weinstein Rule and the ambiguities it prompts; Part III explores the "contingent fee tax

\footnotetext{
1 John Wagner, Trump Signs Sweeping Tax Bill into Law, WASH. Post (Dec. 22, 2017), https:/www.washingtonpost.com/news/post-politics/wp/2017/12/22/trump-signs-sweeping-tax-bill-into-law/ [perma.cc/4G6M-F8N7].

${ }^{2}$ See, e.g., TAX Found., Preliminary Details and Analysis of the Tax Cuts and Jobs Act 4-5 (Dec. 18, 2017), https://taxfoundation. org/final-tax-cuts-and-jobs-act-details-analysis/[perma.cc/DYJ9-EMNR]

${ }^{3}$ I.R.C. $\$ 162(\mathrm{q})$.

${ }^{4} I d$.

${ }^{5}$ Lawrence J. Eisenberg, Insight: The Contingency Fee Tax Trap and a Solution, BLoOMBERG TAX: DAIY TAX REPORT (Aug. 21, 2018), https://news.bloombergtax.com/daily-tax-report/insight-the-contingencyfee-tax-trap-and-a-solution [perma.cc/79T6-C4LL].
} 
trap" in detail, recommends legislative and administrative fixes, and analyzes the efficacy of potential taxpayer attempts to avoid it; and Part IV concludes.

II. THE NEW SECTION 162(Q): THE HARVEY WEINSTEIN RULE

As part of the 2017 Tax Act, Congress enacted section 162(q): a new deduction disallowance provision responding to social concerns arising out of the allegations against Harvey Weinstein and the related "Me Too" movement. ${ }^{6}$ Section 162(q)(1) denies a taxpayer's deduction for "any settlement or payment related to sexual harassment or sexual abuse if such settlement or payment is subject to a nondisclosure agreement." ${ }^{7}$ Section 162(q)(2) goes on to deny deductions for the payor's attorney's fees related to such a settlement or payment. ${ }^{8}$ Prior to the enactment of section $162(\mathrm{q})$, payments or settlements of legal claims by businesses and any related legal fees would generally be deductible, regardless of the nature of the underlying claim or whether the payments were subject to an NDA. ${ }^{9}$

\section{A. The Economics of Section 162(q) \\ 1. Cost-Shifing to Plaintiffs}

The apparent purpose of section 162(q) is to discourage NDAs in sexual misconduct settlements by raising the defendant's costs of those settlements. For example, assume that a corporation settles a harassment case for $\$ 1,000,000$. If the settlement does not include an NDA, the $\$ 1,000,000$ would be deductible and, assuming the corporation has sufficient taxable income, would reduce the corporation's federal income tax liability by $\$ 210,000 .{ }^{10}$ The after-tax cost of the settlement is therefore only $\$ 790,000 .{ }^{11}$ If, on the other hand, the settlement includes an NDA, no deductions would be allowed and the aftertax cost would equal the pre-tax cost of $\$ 1,000,000$.

At first glance, it might appear that section 162(q) only burdens the defendant. In the example above, the cost of including the NDA is $\$ 210,000$, which is paid by the defendant in the form of additional federal income taxes. But this fails to consider bargaining dynamics, which will often result in plaintiffs being burdened as well. A typical plaintiff desires to "sell" nondisclosure to the defendant at the highest possible price. ${ }^{12}$ Section 162(q) burdens that sale by denying the defendant an otherwise available tax deduction. Section $162(\mathrm{q})$ is therefore a tax on the sale of nondisclosure. While the nominal burden of the tax is on the defendant who is seeking the protection of the NDA, and who must pay higher taxes due to the denied deduction, the economic burden can be partially or wholly shifted through lower settlement values. This scenario is analogous to

${ }^{6}$ I.R.C. $\$ 162(q)$.

${ }^{7}$ Id.

${ }^{8} I d$. The statutory language could be interpreted to suggest that deductions for the payee's attorney's fees are disallowed, however, the IRS has indicated that the disallowance applies only to the pavor's attomey's fees. See Section 162(q) FAQ, I.R.S. (Jan. 17, 2020), https://www.irs.gov/newsroom/section-l62q-faq [perma.cc/NF2G-B9SQ] [hereinafter IRS, Section 162(q) FAQ].

${ }^{9}$ Cf. Rev. Rul. 80-211, 1980-2 C.B. 57 (ruling that punitive damages incurred in connection with a trade or business are deductible as ordinary and necessary business expenses under section 162).

${ }^{10} \$ 1,000,000 \times 21 \%$ (current federal corporation income tax rate) $=\$ 210,000$.

$11 \$ 1,000,000$ (pre-tax settlement amount) $-\$ 210,000$ (tax benefit from deductions) $=\$ 790,000$.

12 See Jan Frankel Schau, Where Confidentiality and Transparency Collide, 25 DisP. Resol. MAG. 6 , 8 (2019) ("In practical terms, confidentiality is often a huge incentive, providing leverage for the plaintiff and her lawyer in early settlement negotiations ... For most employees, payment of damages, an apology or explanation, and a commitment by the employer to make changes to ensure that the misconduct will not be repeated are sufficient compensation, and they have no need to publicize their settlement - especially if this means they will get higher damages in exchange for keeping the settlement confidential."). 
a sales tax that is formally paid by the seller, but is often shifted, at least to some extent, to the buyer in the form of a higher price. ${ }^{13}$

For instance, in the example above, before section $162(q)$, the $\$ 1,000,000$ settlement with an NDA would have cost the defendant only $\$ 790,000$ after tax. ${ }^{14}$ After the enactment of section 162(q), the same settlement will now cost the defendant $\$ 1,000,000$ on an after-tax basis. The defendant might respond to section 162(q) in one of two ways, either of which would shift at least some of the nominal burdens of section 162(q) onto the plaintiff.

First, the defendant could reduce its settlement offer to account for nondeductibility. ${ }^{15}$ If the defendant has sufficient bargaining power, it could shift the entire burden of section 162(q) onto the plaintiff by offering only $\$ 790,000$ to settle the case with an NDA. In that situation, the total after-tax cost of the settlement to the defendant would be the same as before the enactment of section 162(q). Accordingly, section 162(q) would then burden only the plaintiff. Alternatively, the burden could be shared between the plaintiff and defendant, resulting in a settlement amount between $\$ 790,000$ and $\$ 1,000,000$.

Second, the defendant could no longer insist on including an NDA in the settlement. The NDA would have had some value to the defendant, so its omission would correspondingly reduce defendant's settlement offer by that value. ${ }^{16}$ If the NDA had a value of $\$ 100,000$ to the defendant and if the defendant would have been willing to settle the case with an NDA for $\$ 1,000,000$ before the enactment of section 162(q), then the defendant should now offer only $\$ 900,000$.

In these examples, the defendant either loses tax deductions or the benefits of an NDA due to the nominal burdens of section 162(q) imposed on the defendant. However, as illustrated here, the defendant can shift some or all of the economic burden to the plaintiff by reducing its settlement offer to offset either loss. In the extreme case, the reduction could shift the entire burden to the plaintiff; in other cases, the burden would be shared by the two parties. Either way, section 162(q) will unwittingly burden sexual misconduct plaintiffs by lowering the values of the settlements they receive. ${ }^{17}$

13 See Mark J. Cowan, Nonprofits and the Sales and Use Tax, 9 FLA. TAX REV. 1077, 1132 (2010).

$14 \$ 1,000,000-(\$ 1,000,000 \times 21 \%)=\$ 790,000$.

${ }^{15}$ See Schau, supra note 12 , at 9 ("[T]hese settlements can readily reach well into six figures, and the business deduction usually realized under corporate tax codes makes that expense much more palatable to a business."); see also Trey Cooper, Tax Cuts and Jobs Act Limits Business Expense Deduction For Settlement of Sexual Harassment Claims, 53 ARK. LAw. 32, 33 (2018) "Because settlement amounts and legal costs are no longer deductible if there is a nondisclosure agreement . . . settlement amounts may be lower.").

${ }^{16}$ See Schau, supra note 12 , at 8-9 (" $[\mathrm{An}]$ employer may actually be trying to make things right by paying serious settlement money to the plaintiff but will not do so willingly if the employer also must suffer the negative publicity from a public disclosure that its employee, especially someone in a leadership role, failed to abide by the employer's own policies.").

${ }^{17}$ Previous commentators have posited that some plaintiffs will be burdened in another way. They argue that some plaintiffs desire a nondisclosure provision to prevent defendants from disclosing embarrassing or otherwise harmful information about them. If section 162(q) leads a defendant to prefer avoidance of an NDA to retain its tax deductions, such plaintiffs could be harmed. See Cooper, supra note 15, at 33; Shane Rader, The Weinstein Tax: Congress' Attempt to Curb Non-Disclosure Agreements in Sexual Harassment Settlements, 3 Bus. Entrepreneurship \& TAX L. Rev. 329, 336 (2019). This assumes that section 162(q) applies to "unilateral" NDAs that benefit only plaintiffs, an issue that is discussed further below. 


\section{Disincentivizing Settlement}

Section 162(q) can also harm plaintiffs in a somewhat different way by encouraging defendants to not settle cases. ${ }^{18}$ The intuition here is that damages paid pursuant to a judgment remain deductible, while settlements that include an NDA are not. Under prior law, all of these costs would have been equally deductible. ${ }^{19}$

To illustrate this incentive, consider a simple case with the following facts. There is a $50 \%$ chance that the plaintiff can establish liability at trial. If such liability is established, damages would be $\$ 2,000,000$. If settled, the defendant would insist on an NDA because it does not want to signal that the plaintiff's allegations have merit.

Prior to the enactment of section 162(q), to settle the case before trial, the largest settlement offer the defendant should accept is $\$ 1,000,000$. If the defendant declines the offer and ultimately prevails at trial, it would pay nothing. If the defendant ultimately loses at trial, the defendant would incur costs of $\$ 2,000,000$ in damages. Because the trial is assumed to be a coin flip, the defendant's expected cost is the average of the two possible outcomes, which is $\$ 1,000,000$. Thus, a risk-neutral defendant should settle the case for any amount not in excess of $\$ 1,000,000$. Importantly, absent section 162(q), the defendant's costs (if any) in each of the three possible outcomes (settlement, defense verdict at trial, or plaintiff victory at trial) are deductible, so there is no need to account for tax adjustments in this analysis.

After the enactment of section 162(q), the defendant must consider tax adjustments in evaluating potential outcomes. A settlement involving an NDA would be nondeductible. On the other hand, if the case goes to trial and the defendant loses, those damages would be deductible. The pre-tax costs if the case goes to trial are $\$ 0$ or $\$ 2,000,000$ if the defendant wins or loses, respectively, and the after-tax costs, assuming the defendant is a corporation, are $\$ 0$ or $\$ 1,580,000 .{ }^{20}$ The average of those two amounts is $\$ 790,000$. Because a settlement of the case would not be deductible, this amount is the highest settlement offer that the defendant should be willing to accept.

Accordingly, if the plaintiff's reservation price for settlement were to fall somewhere between $\$ 790,000$ and $\$ 1,000,000$, section $162(q)$ would impede a settlement that would have occurred prior to its enactment. While this works to the plaintiff's benefit if the plaintiff ultimately prevails at trial, if the plaintiff loses at trial, the outcome could very well be devastating. Instead of reaching a settlement where the plaintiff walks away with hundreds of thousands of dollars (even after attorney's fees and taxes on the settlement), the plaintiff is left empty-handed. ${ }^{21}$

${ }^{18}$ See Cooper, supra note 15 , at 33 ("Because settlement amounts and legal costs are no longer deductible if there is a nondisclosure agreement, early settlement of claims based on sexual harassment or sexual abuse may be less common ...").

${ }^{19}$ See I.R.C. $\$ 162($ a) (allowing deductions for business expenses).

${ }^{20} \$ 2,000,000$ (damages paid) $\times(1-21 \%$ corporate tax rate) $=\$ 1,580,000$

21 This incentive for defendants to "litigate harder" could be even more pronounced depending on how the IRS interprets section 162(q)(2). Section 162(q)(2) denies deductions for attorney's fees "related to" a settlement or payment in a sexual misconduct case involving an NDA. A broad interpretation of "related to" would cover all attomey's fees connected to the litigation; a narrower one would apply only to attorney's fees specifically in connection with negotiating the settlement, the payment, and the associated NDA. This issue of interpretation is discussed in depth below. If the broader interpretation prevails, it could apply to very large attorney's fees, spanning a number of years. In that case, if the defendant views paying more attorney's fees as increasing the likelihood of a defense verdict, the incentive to litigate harder arising out of section 162(q) would be exacerbated because the resultant substantial legal fees would be deductible only if the defendant does not settle the case. 
Note that these burdens apply only to sexual misconduct claimants who enter into NDAs. The apparent justification is that the public interest in bringing these claims to light outweighs the burdens imposed on victims. But even assuming that this is the case, the logic behind section 162(q) is not unassailable. Other claims-such as racial discrimination-may have an equally strong transparency interest, yet section 162(q) does not apply to them. And even though the provision may deter the use of an NDA, the absence of an NDA does not ensure a full public airing of the facts. As mediator Jan Frankel Schau has noted, in sexual harassment cases, "[i]t is often the case that neither the employer nor the employee wants the publicity and potential embarrassment that comes from a public airing of this type of very personal experience." 22 Therefore, even without an NDA, many settling plaintiffs will prefer to keep their allegations private.

\section{B. Ambiguities in Section 162(q)}

As there are only about forty words total in section 162(q), it is unsurprising that significant ambiguities and uncertainties exist regarding how the provision actually operates. Presumably, the government will eventually issue guidance fleshing out the rule, but until then, defendants and the IRS will have to work with the bare-bones statutory provision, which reads in its entirety as follows: "No deduction shall be allowed under this chapter for-(1) any settlement or payment related to sexual harassment or sexual abuse if such settlement or payment is subject to a nondisclosure agreement, or (2) attorney's fees related to such a settlement or payment." ${ }^{23}$

\section{The Problem of Multiple Claims and Global Settlements}

Many cases involve multiple claims that are resolved with a global settlement that settles all claims in exchange for a payment by the defendant. For example, a complaint filed by an employee against an employer could include allegations of racial discrimination, gender discrimination, and breach of contract. As part of the discrimination allegations, the complaint could make specific factual allegations of harassment based on the plaintiff's race or gender. If, as is typical, the case is settled with a payment by the defendant for a global release of all plaintiff's claims, how does section 162(q) apply if the settlement includes an NDA?

The issue depends on the interpretation of "any settlement ... related to sexual harassment." ${ }^{24}$ At one extreme, the term could refer to any settlement that accompanies a release of potential sexual misconduct claims, even if such claims were never alleged and do not exist. Under this reading, any general release of all claims, whether alleged or not,

${ }^{22}$ Schau, supra note 12 , at 8 .

${ }^{23}$ I.R.C. $\$ 162(q)$. Robert Wood has argued that it is possible that the denial of attorney's fees in section 162(q)(2) could apply to sexual misconduct settlements that do not include an NDA. See Robert W. Wood, Tax Write-Offs in Sexual Harassment Cases After Harvey Weinstein, 90 N.Y. ST. BAR J. 10, 12-13 (2018). However, a careful reading of the statutory language should preclude this possibility. The term "such settlement or payment" in section $162(q)(1)$ refers to all sexual misconduct settlements or payments. If section $162(q)(2)$ also used "such settlement or payment," then it would also apply to that entire universe. Because section 162(q)(2) instead uses the term "such a settlement or payment" (emphasis added), the paragraph refers only to the settlement or payments affected by section 162 (q)(1) (i.e. only sexual misconduct payments or settlements that include an NDA). This technical interpretation is supported by logic as well. If one reads section 162(q) the way that Wood suggests, in sexual misconduct cases that do not involve an NDA, the defendant's attorney's fees are non-deductible even though the underlying settlement or payment remains deductible. It is difficult to divine a policy reason for that result and, in any event, there is no indication in the legislative history or context that Congress was concerned about deductions for attorney's fees but not the underlying settlement in cases not employing NDAs.

\footnotetext{
${ }^{24}$ I.R.C. $\$ 162(q)$.
} 
would trigger the application of section 162(q), as such latent or hypothetical sexual harassment claims are thereby waived. As a result, even a garden-variety separation agreement executed to receive severance payments could be subject to section 162(q), assuming the separation agreement includes both a general release and an NDA. ${ }^{25}$ While this would seem to be an unreasonable interpretation, cautious employers might specifically carve allegations of sexual misconduct out of the NDA's coverage. ${ }^{26}$ Alternatively, employers might include in the separation agreement "representations from the employee that the employee has not asserted and has no knowledge of any claims of sexual harassment or sexual abuse."27

A somewhat less extreme interpretation would cover general releases only if an allegation of sexual harassment or abuse has been made. This would exempt gardenvariety severance deals but would also encourage strategic pleading behavior discussed in depth below. Under this interpretation, if an allegation of sexual misconduct has been made, section 162(q) would apply to the entire settlement. ${ }^{28}$

On the other end of the spectrum, the provision could apply only to the portion of the settlement that is allocable to the sexual misconduct allegations, but not to the remaining portions. ${ }^{29}$ Thus, in the example above, assuming a general release with an NDA is executed, while the portion of the settlement allocable to the sexual misconduct claim would be non-deductible, the residual settlement amount would remain deductible. ${ }^{30}$

While at first glance this allocation approach seems straightforward, in practice it would be difficult, if not impossible, to enforce. Allocations of settlements are required in other tax contexts. For example, in personal physical injury cases, because compensatory damages are generally tax-free while punitive damages are taxed, global settlements must be allocated between the compensatory portion and the punitive portion. ${ }^{31}$ In employment cases, lost wages are subject to employment taxes while other damages (such as those for emotional distress or medical distress) are not. ${ }^{32}$ Well-advised plaintiffs insist that settlement agreements aggressively allocate larger amounts to the tax-preferred damages. ${ }^{33}$

${ }^{25}$ See Cooper, supra note 15 , at 33 ("It is possible the IRS could take the position that a general release of employment-related claims includes claims based on sexual harassment or sexual abuse, and a separation payment is related to the release of potential sexual harassment or sexual abuse claims.").

${ }^{26} I d$.

${ }^{27} \mathrm{Id}$.

${ }^{28}$ See Wood, supra note 23, at 13-14 (considering the possibility that "any mention of [sexual harassment] claims" might implicate section 162(q) and "bar any tax deduction, even if the sexual harassment part of the case is minor").

${ }^{29}$ Some commentators have suggested entering into multiple settlement agreements at the same time. See, e.g., Cooper, supra note 15, at 33 (explaining a strategy "to settle the sexual harassment and/or sexual abuse claim in a separate agreement than the remaining claims ..."). However, the IRS would surely view the transaction as one single global settlement under substance over form principles.

${ }^{30}$ See Kelsey K. Crosse, Confidential Sexual Harassment Settlements Fall Victim to TCJA, 24 IowA EMP. L. LETTER 5 (2018) ("Can an employer maximize its tax savings if multiple claims are alleged by allocating the settlement proceeds so that a limited amount is attributed to the sexual harassment claim? Time will tell."); Wood, supra note 23 , at 14 ("Could plaintiff and defendant expressly agree on a particular tax allocation of the settlement to head off the application of the Weinstein tax?").

${ }^{31}$ See Gregg D. Polsky \& Dan Markel, Taxing Punitive Damages, 96 VA. L. REv. 1295, 1344 (2010) (" $[1] \mathrm{n}$ settlements of personal physical injury claims that could have generated punitive damages, a plaintiff must make these difficult allocations.")

32 See T.A.M. 2002-44-004 (June 19, 2002) (concluding that payments by an employer for emotional distress and reimbursement of attorney fees and costs are not subject to employment tax).

${ }^{33}$ See Polsky \& Markel, supra note 31, at 1329-30 (explaining the incentives for parties to allocate aggressively towards excludable damages). 
Aggressive allocations are nearly impossible for the IRS to police in pretrial settlements. ${ }^{34}$ This is because allocations are essentially a valuation exercise. ${ }^{35}$ How much is each part of the claim individually worth? This question presents a substantial challenge, as there is no market for particular types of claims, independent of other related claims. ${ }^{36}$ Although there is a growing market for tort claims in general, plaintiffs rarely, if ever, sell their punitive damage claims while retaining their compensatory claims, or vice versa. In addition, the value of a claim depends on the unique facts that form the basis of the lawsuit. Those facts would only be fully developed at trial, which the pretrial settlement in question itself has foreclosed.

Making matters worse, the counterparty to the settlement is usually indifferent to the tax-driven allocation. For defendants, both compensatory damages and punitive damages are deductible to the same extent. ${ }^{37}$ As a result, aggressive allocations away from punitive damages help plaintiffs tax-wise but have no tax impact on defendants. Defendants are perfectly willing to agree to plaintiff-friendly allocations in the interest of facilitating settlement. ${ }^{38}$ Of course, the IRS is not technically bound to agreed-upon allocations, but in practice, the IRS has great difficulty in challenging them due to the valuation difficulties previously explained. ${ }^{39}$

Returning to the context of section 162(q), if allocations of settlements were required, it can be expected that parties would routinely allocate a very low amount to the sexual misconduct allegations and a significant majority of the recovery to the remaining allegations. ${ }^{40}$ If respected, these allocations would allow defendants to deduct nearly the entire settlement while still obtaining an NDA. Plaintiffs would be unaffected tax-wise by the aggressive allocation and therefore would likely not object so as to maximize the settlement amount. In theory, the IRS could challenge the allocation, but, just as in the case of allocations between compensatory and punitive damages, it would be an uphill battle except in the most egregious of situations.

\section{What Constitutes a Non-Disclosure Agreement for Section I62(q) Purposes?}

Section 162(q) does not define the term "nondisclosure agreement," raising questions about the term's scope. One issue is whether unilateral NDAs that protect only plaintiffs trigger the non-deductibility rule. As previously noted, in many sexual misconduct cases, plaintiffs are interested in ensuring that the allegations and settlement

${ }^{34}$ See $i d$. at 1330 . However, if the case is settled after a jury verdict delineating the various amounts of damages, the IRS might stand a fighting chance. See id. at 1330, 1333.

35 See id. at 1332 "Allocations depend on the relative values of the plaintiff's compensatory and punitive claims.").

${ }^{36}$ See id. at 1331-32.

${ }^{37}$ Rev. Rul. 80-211, 1980-2 C.B. 57.

${ }^{38}$ See Polsky \& Markel, supra note 31, at 1334 ("There is no benefit (tax or otherwise) to be gained by either party in making explicit allocations to punitive damages; however, there are often tax, insurance, or public relations benefits to be gained by avoiding explicit allocations to punitive damages.").

${ }^{39}$ See Wood, supra note 23 , at 15 ("Of course, the IRS is never bound by an allocation in a settlement agreement. But the IRS does often pay attention to such allocations and (in my experience) often respects them."); Polsky \& Markel, supra note 31, at 1334-35 (explaining that allocations in settlements agreements away from punitive damages are very difficult for the IRS to rebut).

40 See Wood, supra note 23 , at 15 ("I expect that we will start seeing such explicit sexual harassment allocations. We may see aggressive allocations, where the sexual harassment may have been the primary impetus of the case. We may also see such allocations, presumably with nominal dollar amounts, even in cases where the claims are primarily about something else."). 
remain private. ${ }^{41}$ Such a plaintiff might insist on a unilateral NDA that prevents the defendant (but not the plaintiff) from disclosing the allegations or the settlement. However, to allow the defendant to protect itself in the court of public opinion, the unilateral NDA might include a provision allowing the defendant to disclose the information if the plaintiff does so first. If so, the defendant might feel comfortable that the self-interest of the plaintiff in keeping the matter private would protect the defendant's interest in privacy even though the plaintiff technically retains the unfettered right to disclose the information.

Would such a unilateral NDA trigger section 162(q)? The limited statutory language offers no guidance. On the one hand, a unilateral NDA is still a type of NDA, and some commentators have assumed that unilateral NDAs would thus implicate section 162(q). ${ }^{42}$ On the other hand, section 162 (q) is clearly targeted at defendants, not at plaintiffs, and unilateral NDAs directly benefit only plaintiffs (though, as explained above, they can indirectly protect defendants). The IRS has already recognized in another context that the legislative target of section 162(q) was defendants not plaintiffs, notwithstanding its broad language. Section 162(q)(2)'s disallowance of deductions for attomey's fees "related to" a sexual misconduct settlement could plausibly be interpreted to apply to plaintiff-side attorney's fees, ${ }^{43}$ but the IRS has explained in informal guidance that the disallowance applies only to defense-side attorney's fees. ${ }^{44}$ The IRS could similarly take the position that NDAs that explicitly protect only plaintiffs are not NDAs for purposes of section 162(q).

Another ambiguity involves pre-existing NDAs. ${ }^{45}$ Employers often require new employees to execute broad NDAs as a condition of their employment. What if a settlement agreement in a sexual harassment claim does not include an NDA but leaves the pre-existing NDA, which covers, among other things, disclosures relating to that claim, intact? While section 162(q) appears to contemplate NDAs that are executed in connection with a settlement, the language is certainly broad enough to capture pre-existing NDAs if the allegations in the claim are covered by the language of the NDA. ${ }^{46}$ Accordingly, a careful defendant that wants to ensure deductibility should explicitly carve out the settlement and its underlying allegations from the pre-existing NDA's scope in the settlement agreement.

Finally, there is the question of whether a provision that restricts, limits, or conditions disclosure, but does not absolutely preclude disclosure, would constitute an NDA for purposes of section 162(q). On one end of the spectrum, a settlement could give the plaintiff the unfettered and unconditional right to disclose any and all information regarding the defendant; this would obviously not constitute an NDA. On the other end of that spectrum, a settlement could preclude any disclosure whatsoever; this would undoubtedly be an NDA.

Between those two extremes there exists a host of potential fact patterns, as mediator Jan Frankel Schau has explained:

${ }^{41}$ See Schau, supra note 22 and accompanying text.

42 See Rader, supra note 17, at 336-37 (arguing that a legislative change would be necessary to exempt unilateral NDAs from section 162(q)'s scope).

${ }^{43}$ See Crosse, supra note 30, at 5; Wood, supra note 23, at 13; Cooper, supra note 15, at 33.

${ }^{44}$ IRS, Section $162(q)$ FAQ, supra note 8.

${ }^{45}$ See Rader, supra note 17 , at 341 ("It is unclear if [section 162(q)] would apply to NDAs previously entered into between the victim and employer.").

${ }^{46}$ Section $162(q)$ only requires that the settlement be "subject to" the NDA. I.R.C. $\S 162(q)(1)$. 
[T] he parties can negotiate the terms of the confidentiality and reflect that in their agreement so that it does not rise to the level of a "non-disclosure agreement." For example, the claims and terms of agreement may be disclosed "upon request" by subpoena or in the course of other legal processes but may not be subject to general disclosure via media or other private communication except to a spouse, attorney, or accountant.

[Alternatively], the parties can cooperate in drafting an approved statement that will constitute the public disclosure if either party is asked. For example, specific language could state "The parties to this lawsuit have decided it is in both side's best interests to resolve the pending dispute in order to focus upon business and personal matters. Accordingly, effective immediately, employee has dismissed her claims against the employer and any further inquiries should be directed to the human resources director."

Finally, the parties can expressly expunge all preliminary non-disclosure agreements but maintain that the terms of the settlement will not be publicized without notice to the company in advance-and if the terms are made public, provide for an opportunity to craft an acceptable statement to release to current employees and to the public. ${ }^{47}$

While Schau believes that the above provisions would not be treated as NDAs for purposes of section 162(q), ${ }^{48}$ that conclusion is not entirely free from doubt because the statute is ambiguous regarding the definition of NDAs. Presumably when the Treasury and the IRS promulgate regulations, they will include guidance on this issue.

\section{What are "Related" Attorney's Fees?}

Section 162(q)(2) denies deductions for "attorney's fees related to . . . a settlement or payment" in a sexual misconduct case where the settlement or payment is subject to an NDA. ${ }^{49}$ Defendants may pay attorney's fees over several years, beginning when allegations are first made and often ending with the negotiation of a settlement agreement. It seems clear that attorney's fees incurred in negotiating and drafting the settlement agreement are covered by section 162(q). But what about earlier fees, such as those for initially investigating the allegations, responding to a demand letter, drafting and filing an answer and other pleadings, engaging in discovery, and attending mediation?

The answer depends on the interpretation of the term "related to." If narrowly interpreted, only attorney's fees that specifically relate to the settlement and NDA themselves would implicate section 162(q). Earlier attorney's fees would remain deductible. This interpretation seems to best comport with the specific words used by Congress in that only deductions for attorney's fees that relate to the "settlement or payment" of damages are denied. If Congress intended that earlier attorney's fees be denied, it could have denied deductions for fees related to "allegations of sexual harassment or sexual abuse" rather than merely those related to "settlement or payment" of damages.

This narrow interpretation is also supported by practical tax compliance realities. Litigation often spans multiple tax years-a defendant may incur attorney's fees in Years 1 through 5 with respect to a claim that is ultimately settled in Year 5. It is a fundamental

\footnotetext{
${ }^{47}$ Schau, supra note 12 , at 10.

${ }^{48} \mathrm{Id}$. at $9-10$.

${ }^{49}$ I.R.C. $\$ 162(q)(2)$.
} 
axiom of federal income tax law that a taxpayer prepares its return based on the facts that are known as of the end of the tax year. ${ }^{50}$ The defendant therefore must decide whether to deduct its Year 1 attorney's fees as of the end of Year 1 based on the facts that then exist.

Under a broad interpretation of section 162(q)(2), deductibility depends on whether the defendant will ultimately enter into a settlement agreement that includes an NDA, a fact unknown in Year 1. Perhaps no settlement will ever be negotiated, and the case will proceed to trial. Or perhaps the parties might negotiate a settlement that does not include an NDA. Alternatively, the claim could be disposed of pursuant to a motion to dismiss or a motion for summary judgment. In any of these situations, section 162(q)(2) would not bar deductions for attorney's fees, but if the claim is ultimately resolved through a settlement that includes an NDA, the attorney's fees would be subject to disallowance under the broader interpretation, leaving the defendant in a difficult position regarding its tax compliance obligations. ${ }^{51}$

A narrow interpretation avoids this problem and appears most faithful to the words used by Congress. One specific issue with a narrow interpretation, however, is when nondeductibility begins. Treasury Regulations in an analogous context, where a business expands by acquiring another business, may be instructive here. ${ }^{52}$ The issue in that context is whether the costs incurred in connection with the acquisition are immediately deductible. Federal tax law has historically drawn a distinction between general investigatory costs, which are immediately deductible, and costs incurred thereafter to acquire a specific business, which are capitalized rather than deducted immediately. ${ }^{53}$

Regulations promulgated in 2003 helpfully elaborate on this line-drawing exercise in the mergers and acquisitions context. ${ }^{54}$ In general, under these regulations, costs incurred before the date on which a letter of intent is executed by both parties are immediately deductible, while costs incurred after that date are not. ${ }^{55}$ However, certain specified costs are not immediately deductible regardless of when they are incurred ${ }^{56}$ These per se non-deductible costs include expenses of appraisal and those incurred in the preparation of transactional documents (e.g., merger agreements) ${ }^{57}$

A similar approach could be used in the section 162(q)(2) context, which would allow deductions for attorney's fees incurred before the date on which the general terms of a settlement that includes an NDA have been agreed upon (whether in a written document or orally), while disallowing all subsequent attorney's fees. Certain attorney's fees, such as those incurred to draft or review a settlement agreement or language therein (including

\footnotetext{
${ }^{50}$ Erik M. Jensen, The Deduction of Future Liabilities by Accrual-Basis Taxpayers: Premature Accruals, the All Events Test, and Economic Performance, 37 U. FLA. L. REV. 443, 465 (1985).

${ }^{51}$ This problem, however, is not completely intractable. Defendants could make their best guesses about how claims will be resolved and then correct their errors when the case is ultimately resolved. For example, if a defendant claims deductions in earlier years for a case that ultimately settles with an NDA, the defendant would "recoup" the earlier deductions in the year of settlement by including them in gross income. However, such an approach would still be fraught with difficulties. For instance, the earlier deductions could be challenged by the IRS as not sufficiently probable to justify their deduction. In addition, the time-value of money and the possibility of tax rate fluctuations could cause the ex post remedy to be highly imprecise.

${ }^{52}$ See Treas. Reg. $\$ 1.263(\mathrm{a})-5(\mathrm{e})$.

${ }^{53}$ Lawrence Lokken, Capitalization: Complexity in Simplicity, 91 TAX NoTES 1357, 1366 (2001); Rev. Rul. 99-23, 1999-1 CB 998.

54 See Treas. Reg. $\$ 1.263(\mathrm{a})-5(\mathrm{e})$.

${ }^{55}$ Treas. Reg. $\S 1.1 .263(\mathrm{a})-5(\mathrm{e})(1)(\mathrm{i})$.

${ }^{56}$ Treas. Reg. $\S 1.263(\mathrm{a})-5(\mathrm{e})(2)$.

${ }^{57} \mathrm{Id}$.
} 
the terms of an NDA), would be per se non-deductible, regardless of when they are incurred (assuming of course that the settlement ultimately includes an NDA) ${ }^{58}$

While a narrow interpretation is the most reasonable, there are arguments in favor of a broad interpretation. Although the legislative history behind section 162(q) is exceptionally sparse, it arguably supports the broad interpretation. ${ }^{59}$ The disallowance of deductions for payments related to sexual harassment settlements and associated legal fees was not included in the original House bill, but added later through a Senate amendment. ${ }^{60}$ In the Conference Report, the Senate amendment, which ultimately became section 162(q), described the provision as follows: "Under the provision, no deduction is allowed for any settlement, payout, or attorney fees related to sexual harassment or sexual abuse if such payments are subject to a nondisclosure agreement." ${ }^{.61}$ This language is consistent with a broad interpretation because it conditions disallowance on the attorney's fees relating to the underlying sexual harassment or sexual abuse. Thus, the language of the Conference Report is suggestive of a broad interpretation.

There is also a policy argument in favor of a broad interpretation. In a protracted litigation, the narrow interpretation could mean that the vast majority of attorney's fees will remain deductible even though the ultimate settlement includes an NDA. Only the attorney's fees very close to the "finish line" would be non-deductible, as would (of course) the settlement itself. This could exacerbate section 162(q)'s perverse incentive of discouraging settlement. For instance, assume that a defendant believes that for each dollar of additional attorney's fees spent, it will reduce the eventual settlement (which will include an NDA) by $\$ 0.95$. Absent section 162(q)(2), this state of affairs should cause the defendant to immediately settle the case, because prolonging the litigation is more costly than settlement. But with the advent of section 162(q)(2), in conjunction with a narrow interpretation of its language, this incentive is turned on its head, assuming the attorney's fees are deductible. This is because the after-tax cost of one dollar of attorney's fees would equal $\$ 0.79$, while the after-tax cost of $\$ 0.95$ of settlement will remain $\$ 0.95 .{ }^{62}$ Accordingly, the defendant should not settle. A broad interpretation would mitigate this problem because all of the defendant's attorney's fees would be non-deductible. This sort of policy analysis is presumably what motivated Congress to deny deductions not only for settlements but for related attorney's fees as well. A tax incentive for defendants to pay greater attorney's fees to bid down settlement values is obviously problematic.

Despite the purposive and policy arguments that may be offered in support of a broader interpretation, ultimately the statutory language and practical considerations counsel in favor of a narrow interpretation. Furthermore, Congress did not create any mechanism to deal with the multi-year litigation issues that would necessarily arise under

\footnotetext{
${ }^{58}$ A related issue is whether costs of in-house counsel effort would be considered attomey's fees subject to disallowance under section $162(\mathrm{q})(2)$. If so, in-house counsel salaries would have to be allocated between the portion subject to section $162(\mathrm{q})(2)$, which would not be deductible, and the remaining portion, which would be deductible. Such allocations could be difficult for defendants to make and for the IRS to police because in-house counsel generally do not track their time. On the other hand, a rule that flatly exempts all inhouse salaries from section 162(q)(2) would preference in-house legal work over outside counsel. The 2003 Regulations discussed above resolve this dilemma by generally allowing immediate deduction of employee compensation. See Treas. Reg. $\$ 1.263(\mathrm{a})-5(\mathrm{~d})(1)$.

${ }^{59}$ See H.R. REP. No. 115-466, at 431 (2017) (Conf. Rep.)

${ }^{60} \mathrm{Id}$.

${ }^{61} I d$.

${ }^{62}$ The after-tax cost of one dollar of deductible attorney's fees incurred by a corporate defendant would equal $\$ 0.79$ because the dollar of deduction saves the corporation $\$ 0.21$.
} 
the broad interpretation. In sum, the Treasury and the IRS should adopt a narrow interpretation.

\section{Pleading Strategies to Avoid Section 162(q)}

As previously discussed, section 162(q) adversely affects sexual misconduct plaintiffs who wish to maximize their financial recoveries. ${ }^{63}$ These plaintiffs therefore can benefit from avoiding section $162(\mathrm{q})$. One possible strategy would be to consider avoiding or at least delaying the inclusion of sexual harassment claims in demand letters and initial pleadings. ${ }^{64}$ For example, if a claimant has a strong discrimination case even without including sexual harassment claims, the expected value of a future settlement may counterintuitively increase by not making those additional claims. At a minimum, the potential cost due to section $162(\mathrm{q})$ must be weighed against the benefit of including those claims. The ability to amend the complaint adding in sexual harassment claims if the case does not quickly settle, would be a factor in this cost-benefit analysis.

In similar contexts, plaintiffs' lawyers have been advised to craft their complaints with an understanding of federal income tax law. ${ }^{65}$ For example, in personal physical injury cases, compensatory damages are generally tax-free, while punitive damages are taxed. ${ }^{66}$ As a result, commentators have recommended that personal injury plaintiffs avoid specifying punitive damages claims in their initial complaints. ${ }^{67}$

If a sexual harassment count has already been pleaded, plaintiffs could possibly avoid section 162(q) in certain situations by voluntarily dismissing the corresponding count with prejudice. ${ }^{68}$ For example, if the allegations of sexual harassment are extremely weak (either on the facts or on the law), and the claim is voluntarily dismissed early in the case before any serious settlement discussions occur, an eventual settlement should not be subject to section $162(\mathrm{q}){ }^{69}$

${ }^{63}$ See discussion supra Part II.A.

64 This assumes that section 162(q) could apply only in situations where sexual misconduct has been specifically alleged, even where a global release is executed. See discussion supra Part II.B.1.

${ }^{65}$ See Polsky \& Markel, supra note 31 , at 1037 and accompanying text (describing tax-strategic pleading strategies).

${ }^{66}$ See id. at 1311-12; I.R.C. $\S 104(\mathrm{a})(2)$.

67 See Kevin A. Palmer, Recent Developments in the Taxation of Punitive Damage Awards, 73 TAXES 596,600 (1995) ("If the applicable rules of pleading allow them, general demands for damages are preferable to preserve the ability to structure a future settlement on a tax-free basis.").

${ }^{68}$ See Cooper, supra note 15 , at 33 ("If the claim is not based on allegations that reasonably meet the legal standard for sexual harassment or abuse, counsel for the employer may be wise to meet and confer with counsel for the claimant in an attempt to have the claimant voluntarily abandon and/or dismiss the sexual harassment or sexual abuse claim before settling the case. If a lawsuit has been filed, a motion for the court to dismiss or grant summary judgment on a sexual assault or sexual abuse claim may pave the way for a quicker settlement. In fact, some cases (where the allegations of sexual harassment or sexual abuse are weak) may demand that the employer attempt to have the court dismiss or grant summary judgment on sexual harassment or sexual abuse claims before even attempting to settle.").

${ }^{69}$ Note that a plaintiff, in deciding whether to plead or drop a sexual abuse claim, should consider the potential impact on the plaintiff's own tax situation. Plaintiffs may exclude from their gross income damages they received from personal physical injury claims, but not pure emotional distress recoveries. Thus, for example, if a plaintiff's sexual abuse claim is dropped, leaving only emotional distress claims, the plaintiff's recovery will be fully taxed. On the other hand, if the sexual abuse claim is retained, it is possible that the recovery could be excluded from gross income as damages received on account of a personal physical injury. See I.R.C. $\S 104(a)(2)$ 


\section{EXACERBATION OF THE CONTINGENT FEE TAX TRAP}

The 2017 Tax Act significantly exacerbated an existing flaw in the Code that detrimentally affects plaintiffs who pay contingent fees in certain causes of action. ${ }^{70}$ This "contingent fee tax trap" results in the plaintiff paying tax on the full amount of the settlement even though a portion of the settlement is retained by the plaintiff's lawyer as the contingent fee.

The tax trap arises where both (i) the settlement (or a portion thereof) is taxable to the plaintiff and (ii) the plaintiff's deduction for her attorney's fees is classified as a "miscellaneous itemized deduction." deductions could be claimed only to the extent that they (in the aggregate) exceeded $2 \%$ of the taxpayer's adjusted gross income. ${ }^{72}$ Thus, a plaintiff with $\$ 200,000$ of adjusted gross income would lose the tax benefit of the first $\$ 4,000$ of her miscellaneous itemized deductions. ${ }^{73}$ In addition, miscellaneous itemized deductions were disallowed entirely for purposes of the alternative minimum tax (AMT) ${ }^{74}$ The AMT is an alternative to the regular tax system whereby the taxpayer must pay the greater of her AMT liability and her regular tax liability. ${ }^{75}$ If a plaintiff subject to the tax trap received a large settlement, it would likely put her on the AMT, which has a maximum rate of $28 \%{ }^{76}$

The 2017 Tax Act disallowed miscellaneous itemized deductions under the regular tax system (and continued to disallow them under the AMT system) between 2018 and $2025 .^{77}$ This change is set to expire on January 1, 2026, returning to the former regime where miscellaneous itemized deductions were allowed for regular tax purposes only to the extent they exceed $2 \%$ of adjusted gross income (and were entirely disallowed under the AMT). ${ }^{78}$

These rules can be extremely harsh. Consider a plaintiff who settles a case for $\$ 1,000,000$ and pays her attorney a $\$ 400,000$ contingent fee, leaving her $\$ 600,000$ before tax. Before 2018 and after 2025, if the plaintiff were subject to the tax trap, her AMT liability on the award would be approximately $\$ 280,000 .^{79}$ This translates into an effective

${ }^{70}$ Plaintiffs that pay hourly fees could be affected as well, but most plaintiffs in causes of actions relevant for the purposes of this Article retain their lawyers on a contingent fee basis.

${ }^{71}$ See Gregg D. Polsky, Taxing Litigation: Federal Tax Concerns of Personal Injury Plaintiffs and Their Lawyers, 22 FLA. TAX REV. 120, 137-38 (2018) (describing the effect of the 2017 Tax Act's disallowance of miscellaneous itemized deductions on certain personal injury plaintiffs).

${ }^{72}$ See I.R.C. $\$ 67$ (a) (allowing miscellaneous itemized deductions to the extent they exceed $2 \%$ of the taxpayer's adjusted gross income)

$73 \$ 200,000$ adjusted gross income x $2 \%$ "floor" $=\$ 4,000$. Note that miscellaneous itemized deductions are allowed only to taxpayers who choose to itemize their deductions rather than claim the standard deduction. I.R.C. $\S 63(\mathrm{e})$.

${ }^{74}$ See I.R.C. $\S 56(\mathrm{~b})(1)(\mathrm{A})(\mathrm{i})$ (disallowing miscellaneous itemized deductions for the purpose of the AMT).

${ }^{75}$ See generally I.R.C. $\S 55$ (requiring taxpayers other than corporations to pay the greater of their AMT liability or their regular tax liability).

76 See I.R.C. $\$ 55(\mathrm{~b})(1)(\mathrm{A})$ (setting the maximum rate for the AMT at $28 \%$ ).

${ }_{77}$ See I.R.C. $\$ 67$ (g) (suspending miscellaneous itemized deductions through 2025).

${ }^{78}$ See I.R.C. $\$ 67$ (a) (allowing miscellaneous itemized deductions to the extent they exceed $2 \%$ of adjusted gross income); I.R.C. $\S 56(\mathrm{~b})(1)(\mathrm{A})(\mathrm{i})$ (disallowing miscellaneous itemized deductions for the purposes of the AMT).

${ }^{79} 28 \%$ (AMT rate) $\times \$ 1,000,000$ (gross settlement) $=\$ 280,000$. Depending on the plaintiff's other income and deductions, some portion of her AMT taxable income could be subject to the slightly lower rate of $26 \%$. I.R.C. $\$ 55(\mathrm{~b})(1)(\mathrm{A})$. AMT taxpayers also receive the benefit of an exemption amount, but this plaintiff would be phased out of the exemption amount under the AMT rules that applied before 2018 and will apply again after 2025. I.R.C. $\S 55(\mathrm{~d})(1)-(2),(4)$. 
$47 \%$ federal income tax on her net $\$ 600,000$ recovery ${ }^{80}$ even though the statutory rates top out at $37 \%{ }^{81}$ If the attorney fee portion of the claim is higher (because, for example, the attorney incurred substantial costs for expert witnesses), the burden of the tax trap increases. For instance, if the plaintiff retains only $\$ 400,000$ of the settlement (with the attorney receiving $\$ 600,000$ as his contingent fee and recovery of costs), the effective tax rate is $70 \%{ }^{82}$

Between 2018 and 2025, this plaintiff is even worse off. Assuming she is unmarried, has no other income, claims the standard deduction, and pays $\$ 400,000$ of a $\$ 1,000,000$ settlement to her attorney, she would owe roughly $\$ 330,000$ in tax. ${ }^{83}$ This translates into an effective tax rate of $55 \%,{ }^{84}$ which is nearly $50 \%$ higher than the highest statutory rate of $37 \% .{ }^{85}$ If an additional $\$ 200,000$ went to the attorney for reimbursement of costs, her effective tax rate would be over $80 \%{ }^{86}$ If costs surpass $\$ 200,000$, the plaintiff's effective tax rate may approach or even exceed $100 \%$, as shown in Table 1 .

\section{Table 1}

\begin{tabular}{|l|c|c|c|c|c|}
\hline $\begin{array}{l}\text { Year/Tax } \\
\text { type }\end{array}$ & $\begin{array}{c}\text { Gross } \\
\text { settlement }\end{array}$ & $\begin{array}{c}\text { Attorney's } \\
\text { fees and } \\
\text { costs }\end{array}$ & $\begin{array}{c}\text { Net } \\
\text { settlement }\end{array}$ & $\begin{array}{c}\text { Fed. tax } \\
\text { liability }\end{array}$ & $\begin{array}{c}\text { Effective } \\
\text { fed. tax } \\
\text { rate }\end{array}$ \\
\hline $\begin{array}{l}\text { Pre- } \\
\text { 2018/AMT }\end{array}$ & $\$ 1,000,000$ & $\$ 400,000$ & $\$ 600,000$ & $\$ 280,000$ & $47 \%$ \\
\hline $\begin{array}{l}\text { 2020/Reg. } \\
\text { tax }\end{array}$ & $\$ 1,000,000$ & $\$ 400,000$ & $\$ 600,000$ & $\$ 330,000$ & $55 \%$ \\
\hline $\begin{array}{l}\text { Pre- } \\
\text { 2018/AMT }\end{array}$ & $\$ 1,000,000$ & $\$ 600,000$ & $\$ 400,000$ & $\$ 280,000$ & $70 \%$ \\
\hline $\begin{array}{l}\text { 2020/Reg. } \\
\text { tax }\end{array}$ & $\$ 1,000,000$ & $\$ 600,000$ & $\$ 400,000$ & $\$ 330,000$ & $83 \%$ \\
\hline $\begin{array}{l}\text { Pre- } \\
\text { 2018/AMT }\end{array}$ & $\$ 1,000,000$ & $\$ 700,000$ & $\$ 300,000$ & $\$ 280,000$ & $93 \%$ \\
\hline $\begin{array}{l}\text { 2020/Reg. } \\
\text { tax }\end{array}$ & $\$ 1,000,000$ & $\$ 700,000$ & $\$ 300,000$ & $\$ 330,000$ & $110 \%$ \\
\hline
\end{tabular}

$80 \$ 280,000$ (AMT tax) $/ \$ 600,000$ (net settlement) $=47 \%$.

${ }^{81}$ See I.R.C. $\S 1(\mathrm{j})(2)$ (setting out maximum tax rates for taxable years 2018 through 2025).

$82 \$ 280,000$ (AMT tax) $/ \$ 400,000$ (net settlement) $=70 \%$.

83 This is calculated using 2020 tax law. After claiming the $\$ 12,400$ standard deduction, the plaintiff's taxable income is $\$ 987,600$, which, after application of the 2020 tax rates, yields federal income tax liability of $\$ 330,890$.

${ }^{84} \$ 330,000$ (tax liability) $/ \$ 600,000$ (net settlement) $=55 \%$.

${ }^{85}(55 \%-37 \%) / 37 \%=49 \%$.

$86 \$ 330,000$ (tax liability) $/ \$ 400,000$ (net settlement) $=82.5 \%$. 


\section{A. Claims Subject to the Tax Trap}

Many plaintiffs are unaffected by the tax trap. Claims that arise out of personal physical injuries are generally exempt because the plaintiff's recovery is often entirely taxfree ${ }^{87}$ However, punitive damages, post- and pre-judgment interest, and reimbursement of previously deducted medical expenses are taxable, even if the claim arises out of a personal physical injury. ${ }^{88}$ To the extent that a plaintiff receives these components, the tax trap will be implicated. For instance, assume that a personal physical injury plaintiff receives a settlement of $\$ 1,500,000$, two-thirds of which is attributable to pain and suffering (which is received tax-free) and one-third of which is attributable to a taxable component (such as punitive damages or interest). Assume further that the plaintiff pays $\$ 500,000$ to her attorney pursuant to a contingent fee agreement. Because $\$ 500,000$ (onethird of the settlement) is taxable, before the denial of miscellaneous itemized deductions, the plaintiff would have been able to deduct $\$ 167,000$ (one-third of the attorney's fee) ${ }^{89}$ Under current law, no deduction is allowed and the plaintiff is taxed on the full $\$ 500,000$.

Claims that arise out of the taxpayer's trade or business are also unaffected by the trap. This is because the attorney's fees deduction in such cases is classified as an abovethe-line deduction, and above-the-line deductions cannot constitute miscellaneous itemized deductions. ${ }^{90}$ If the plaintiff's claim arises out of the plaintiff's self-employment, the attorney's fees deduction is classified as an above-the-line deduction pursuant to section $62(a)(1){ }^{91}$ If the plaintiff's claim arises out of the plaintiff's employment by another person or entity, the attorney's fees deduction is deductible as an above-the-line deduction pursuant to section $62(\mathrm{a})(20){ }^{92}$

"Civil rights" claims based on federal, state, or local law (whether statutory or common law) are also exempt from the trap because section 62(a)(20) allows an abovethe-line deduction for attorney's fees related to those claims. ${ }^{93}$ Likewise, attorney's fees

\footnotetext{
${ }^{87}$ See I.R.C. $\S 104(a)(2)$ (excluding damages, other than punitive damages, received on account of personal physical injury or sickness).

88 See id.; see also Polsky, supra note 71, at 124 (describing categories of damages received in personal physical injury lawsuits that are not excluded from gross income).

89 See Johnson-Waters v. Comm'r, 66 T.C.M. (CCH) 252, 253 (1993) (allocating attorney's fee
} deduction between taxable and tax-free components on a pro rata basis); P.L.R. 2004-03-046 (Jan. 16, 2004). However, before 2018 (and after 2025) the deduction was subject to the traditional limitations regarding miscellaneous itemized deductions. See I.R.C. $\$ 67(\mathrm{a})$, (g). Accordingly, the plaintiff would be able to deduct miscellaneous itemized deductions only to the extent that they (in the aggregate) exceeded $2 \%$ of the plaintiff's adjusted gross income and these deductions would not be allowed in calculating the plaintiff's AMT liability. Id.

${ }^{90}$ I.R.C. $\S 63(\mathrm{~d})(1)$ (defining itemized deductions as deductions other than above-the-line deductions, which are those that are taken into account in calculating adjusted gross income); I.R.C. $\$ 67(\mathrm{~b})$ (characterizing certain itemized deductions as miscellaneous itemized deductions); see also Gregg D. Polsky, Letters to the Editor: Miscellaneous Itemized Deductions and Litigation Expenses, 160 TAX NOTES 1281 (2018) (explaining the relationship between above-the-line deductions, itemized deductions, and miscellaneous itemized deductions)

${ }^{91}$ I.R.C. $\$ 62(a)(1)$ (allowing an adjustment to gross income for trade and business deductions).

${ }^{92}$ I.R.C. $\$ 62(\mathrm{a})(20)$ (allowing an above-the-line deduction for attomey's fees paid in connection with claims of "unlawful discrimination"); I.R.C. $§ 62(\mathrm{e})(18)(\mathrm{ii})$ (including employment-related claims within the definition of "unlawful discrimination" for purposes of I.R.C. $\S 62(a)(20))$.

${ }^{93}$ I.R.C. $\$ 62(\mathrm{e})(18)(\mathrm{i})$ includes civil rights claims within the definition of "unlawful discrimination" for purposes of I.R.C. $\S 62(a)(20)$. I.R.C. $\S 62(\mathrm{e})(1)$ through (16) provides a list of federal statutory provisions (such as specified sections of the Americans with Disabilities Act) for which attorney's fees deductions will be classified as above-the-line. This list and the "catch-all" provision for civil rights and employment claims appear to be entirely redundant. Cf. I.R.C. $\S 62(\mathrm{e})(1)-(16)$ (listing federal statutes) with I.R.C. $\S 62(\mathrm{e})(18)$ 
paid by whistleblowers to the IRS, the SEC, or the CFTC or by state or federal qui tam whistleblowers are classified as above-the-line deductions, exempting such whistleblowers from the tax trap. ${ }^{94}$ Finally, claims arising out of the damage or destruction of property will not be affected by the tax trap because the legal fees will be added to the adjusted basis of the property. ${ }^{95}$

Claims that fall outside of these descriptions are subject to the tax trap. Thus, the trap will generally apply to claims for defamation or slander, ${ }^{96}$ invasion of privacy, negligent or intentional infliction of emotional distress, private false imprisonment, ${ }^{97}$ badfaith insurance practices, and punitive damages (even if the underlying personal injury was physical in nature).$^{98}$ For these claims, the plaintiff will be required to include the gross settlement in gross income and will not (under current law) receive any deduction for the contingent attorney's fee.

Table 2 shows whether certain claims are subject to the trap and provides explanations for any exemptions.

(catch-all provision describing civil rights and employment claims). For further discussion of this overlap, see infra text accompanying notes 178-183.

${ }^{94}$ I.R.C. § 62(a)(20) (providing above-the-line classification for attorney's fees in connection with a claim of "a violation of subchapter III of chapter 37 of title 31, United States Code," commonly known as qui tam claims, and claims of "unlawful discrimination"); I.R.C. $\$$ 62(a)(21) (providing above-the-line classification for IRS, SEC, CFTC, and state qui tam claims).

${ }^{95}$ For example, if a plaintiff recovers $\$ 10,000$ for damage to his car and pays $\$ 3,000$ as a contingent attorney's fee, the plaintiff will generally reduce his basis in the car by the $\$ 10,000$ recovery and simultaneously increase his basis by the $\$ 3,000$ fee, resulting in a net $\$ 7,000$ reduction in basis. If the plaintiff spends the $\$ 7,000$ to restore his car, basis will return to the original amount. See Big Four Indus., Inc. v. Comm'r, 40 T.C. 1055,1060 (1963), acq., 1964-2 C.B. 3, 4 (stating that, to the extent the property damages award did not exceed basis, it would be nontaxable, but any recovery in excess of basis would be taxable as capital gain); Treas. Reg. $\$ 1.263(\mathrm{a})-3(\mathrm{k})(1)(\mathrm{iii})$ (requiring a taxpayer to capitalize an amount payed for restoration if that restoration is for damage to the property for which the taxpayer has claimed a casualty loss); P.L.R. 1993-08-013 (Nov. 24, 1992) ("Breach of contract damages relating to capitalizable items are generally treated first as a tax-free return of capital, to the extent of the taxpayer's basis in the subject-matter of the contract ... The taxpayer must recognize income, however, to the extent such damages exceed the taxpayer's basis in the subject-matter of the contract."). Because the attorney's fee increases basis (i.e., it is capitalized), it is not deducted and, therefore, the miscellaneous itemized deduction rules are irrelevant. See I.R.C. $\$ 263$; F.S.A. 2002-28-005 (Mar. 29 , 2002) (holding that the legal fees attributable to property damage settlement should be capitalized).

${ }^{96}$ This assumes that the defamation or slander does not relate to the taxpayer's trade or business (other than the trade or business of being an employee). If it does, the fees will be deductible above-the-line. See I.R.C. $\S 62(a)(1)$.

${ }_{97}$ While recoveries related to wrongful incarceration by the government are excluded (and therefore not subject to the tax trap) those related to false imprisonment are taxable. See I.R.C. $§ 139$ F(a) (excluding damages for wrongful incarceration from gross income); Stadnyk v. Comm'r, 96 T.C.M. (CCH) 475, 478 (2008) (holding that "physical restraint and physical detention" in a false imprisonment case "are not "physical injuries" "under I.R.C. $\$ 104(a)(2)$ and, therefore, the damages were not excluded from gross income).

${ }^{98}$ See I.R.C. $\$ 104(a)(2)$ (providing that, while compensatory damages in a personal physical injury case are excluded from gross income, punitive damages are included in gross income). Section 104(c) provides a narrow exception to this rule allowing punitive damages arising out of a physical injury to be excluded in a wrongful death case where the applicable wrongful death law of a state (as in effect on September 13, 1995) provides, or has been construed by a court to provide, that only punitive damages may be awarded in such an action. See also Benavides v. United States, 497 F.3d 526, 530 (5th Cir. 2007) (holding that I.R.C. $§ 104$ (c) does not exclude punitive damages when the general wrongful death laws of the state do not limit recovery to punitive damages, even if some other law, such as workers' compensation law, might have such a limit). 
Table 2

\begin{tabular}{|c|c|c|c|}
\hline Type of claim & Subject to trap? & If not, why not? & Additional comments \\
\hline $\begin{array}{l}\text { Personal physical } \\
\text { injury }\end{array}$ & Generally, no & $\begin{array}{l}\text { Recovery is often } \\
\text { entirely tax-free } \\
\text { under } \S 104(a)(2)\end{array}$ & $\begin{array}{l}\text { If plaintiff receives } \\
\text { taxable components, } \\
\text { then tax trap will apply } \\
\text { to those (see below) }\end{array}$ \\
\hline $\begin{array}{l}\text { Wrongful } \\
\text { incarceration }\end{array}$ & No & $\begin{array}{c}\text { Recovery is tax-free } \\
\text { under } \S 139 \mathrm{~F}\end{array}$ & \\
\hline Employment-related & No & $\begin{array}{l}\S 62(\mathrm{a})(20) \& \\
\text { (e)(18)(ii) allow } \\
\text { above-the-line } \\
\text { deduction }\end{array}$ & \\
\hline $\begin{array}{l}\text { Related to self- } \\
\text { employment }\end{array}$ & No & $\begin{array}{l}\S 62(\mathrm{a})(1) \text { allows } \\
\text { above-the-line } \\
\text { deduction }\end{array}$ & \\
\hline Civil rights & No & $\begin{array}{c}\S 62(\mathrm{a})(20) \& \\
\text { (e)(18)(ii) allow } \\
\text { above-the-line } \\
\text { deduction }\end{array}$ & \\
\hline $\begin{array}{l}\text { The IRS, the SEC, } \\
\text { the CFTC, state and } \\
\text { federal qui tam }\end{array}$ & No & $\begin{array}{c}\$ 62(\mathrm{a})(20) \& \\
\text { (a)(21) allow above- } \\
\text { the-line deduction }\end{array}$ & \\
\hline Property damages & No & $\begin{array}{l}\text { Attorney's fees } \\
\text { added to basis, not } \\
\text { deducted }\end{array}$ & \\
\hline $\begin{array}{l}\text { Taxable components } \\
\text { of personal physical } \\
\text { injury recoveries }\end{array}$ & Yes & N/A & $\begin{array}{l}\text { Applies to allocations } \\
\text { of punitive damages, } \\
\text { interest, and previously } \\
\text { deducted medical } \\
\text { expenses }\end{array}$ \\
\hline $\begin{array}{l}\text { Other types of } \\
\text { claims }\end{array}$ & Yes & N/A & $\begin{array}{c}\text { E.g., defamation, } \\
\text { negligent/intentional } \\
\text { infliction of emotional } \\
\text { distress, invasion of } \\
\text { privacy }\end{array}$ \\
\hline
\end{tabular}

B. Tax Policy Implications

It is an axiom of U.S. federal income taxation that costs incurred in generating gross income are deductible in arriving at taxable income. ${ }^{99}$ Otherwise, a taxpayer would be taxed on her gross, rather than net, income, even though net income is the appropriate

${ }^{99}$ See Hantzis v. Comm'r, 638 F.2d 248, 249 (1st Cir. 1981) (explaining the deductibility of costs incurred in generating gross income). 
measure of a taxpayer's ability to pay. Accordingly, it is not surprising that Congress has almost universally allowed deductions for costs incurred to generate gross income. ${ }^{100}$

In the exceptional cases where Congress has disallowed deductions for these costs, either the costs or the activity itself has been deemed to violate public policy. For example, under section $280 \mathrm{E}$, the costs incurred in the business of trafficking in controlled substances as prohibited by federal or state law are non-deductible. ${ }^{101}$ Likewise, subsections (c) and (f) of section 162 disallow otherwise deductible payments for illegal bribes or kickbacks and for government fines or penalties, respectively ${ }^{102}$

While these and other similar deduction disallowance provisions are targeted narrowly to specific activities or deductions, the denial of miscellaneous itemized deductions is not targeted, as the expenses included within the definition of miscellaneous itemized deductions are varied. ${ }^{103}$ Perhaps the most common types of miscellaneous itemized deductions are unreimbursed employee business expenses. The rationale for disfavoring these expenses is that employers would generally reimburse legitimate employee business expenses, so unreimbursed employee business expenses have a high risk of constituting disguised personal consumption. ${ }^{104}$ While this concern may be valid in some circumstances, some employers may simply lack the financial wherewithal to reimburse all legitimate employee expenses.

Other common types of miscellaneous itemized deductions are expenses related to investments of stocks, bonds, and other financial instruments, such as annual "wrap" fees paid to investment advisors. ${ }^{105}$ It is hard to discern the tax policy rationale for disfavoring these expenses. The best explanation may be that these investments generally produce at least some long-term capital gain that is not currently recognized; therefore, allowing an immediate deduction against ordinary income would be too generous. Although this may be true in general, permanently disallowing any deduction is an excessive response to this concern.

Regardless of the merits of disfavoring these common types of miscellaneous itemized deductions, they are generally small in relation to the taxpayer's income, and therefore denial of these deductions is merely annoying rather than devastating. For employees whose legitimate unreimbursed employee business expenses equal about $1 \%$ of their salary, they would save only about ten to forty dollars in tax per $\$ 10,000$ of salary if the expenses were allowed as above-the-line deductions. Likewise, an investor paying a typical wrap fee of $1 \%$ of investment assets under management would save about the same amount in tax per $\$ 10,000$ of asset value.

On the other hand, plaintiffs who are affected by the contingent fee tax trap often face significant adverse tax consequences because the disallowed deduction is a function

100 See, e.g., I.R.C. $\$ 162$ (allowing deductions for ordinary and necessary costs incurred in connection with carrying on a trade or business); I.R.C. $\$ 212(1)$ (allowing deductions for ordinary and necessary costs incurred in connection with the production or collection of income).

${ }^{101}$ I.R.C. $\$ 280 \mathrm{E}$.

102 I.R.C. $\S 162$ (c), (f).

${ }^{103}$ I.R.C. $\$ 67$ (b) (defining miscellaneous itemized deductions).

104 Jeffrey H. Kahn, Beyond the Little Dutch Boy: An Argument for Structural Changes in Tax Deduction Classification, 80 WASH. L. REV. 1, 31 (2005).

${ }^{105}$ See I.R.C. $\S 212$ (allowing deductions for expenses incurred in connection with investment activity). Section 212 deductions that are not attributable to the production of rents or royalties are generally below-the-line deductions. See I.R.C. § 62(a) (listing above-the-line deductions). Section 67(b) classifies these below-the-line section 212 deductions as miscellaneous itemized deductions. 
of the settlement amount, which can be extremely large, and because contingent fees and costs can constitute a large portion of the settlement. In Table 1, the plaintiff's disallowed fee deduction attributable to a $\$ 1,000,000$ settlement ranged from $\$ 400,000$ to $\$ 700,000$. If instead the deduction were an above-the-line deduction, the plaintiff would have saved between $\$ 150,000$ and $\$ 250,000$ in tax.

Even before miscellaneous itemized deductions were entirely disallowed, commentators recognized the patent unfairness of the contingent fee tax trap. ${ }^{106}$ Prior to 2004, attorney's fees of employment and civil rights claimants were characterized as miscellaneous itemized deductions, subject to the then-existing $2 \%$ floor, and disallowed under the AMT ${ }^{107}$ The fees were often large enough to cause the claimant to pay tax under the AMT, resulting in a very high effective rate of tax on those awards.

Although legislative relief came in $2004,{ }^{108}$ before Congress acted there was a chorus of criticism from courts and commentators. ${ }^{109}$ For example, in a 1995 employment case, the First Circuit explained that "the outcome smacks of injustice because Taxpayer is effectively robbed of any benefit of the Legal Fee's below the line treatment." 110 Senator Chuck Grassley, then chairman of the Finance Committee, referred to the problem as "a tax law fluke that forces plaintiffs who win settlements in civil rights cases and other lawsuits to pay income taxes on parts of the settlements they never see[-]in some cases even owing thousands of dollars more than they win."111 He further explained: "It's clearly a fairness issue to make sure people don't have to pay income taxes on income that was never theirs in the first place. That's common sense." 112

As a result of this criticism, Congress legislatively addressed the tax trap in 2004, but only for a subset of the claims to which the trap applied-namely civil rights and employment claims. ${ }^{113}$ This omission-whether intentional or not-left many other types of claims in the dark. The 2017 Tax Act exacerbated the problem by completely disallowing miscellaneous itemized deductions for regular tax purposes. ${ }^{114}$

106 See Brant J. Hellwig \& Gregg D. Polsky, Litigation Expenses and the Alternative Minimum Tax, 6 FLA. TAX REV. 899, 931 (2004) ("Courts, commentators, and even the National Taxpayer Advocate for years have urged Congress to address the unjust and unfair tax treatment of legal fees under the AMT.") (footnotes omitted).

${ }^{107}$ See Alexander v. Comm'r, 72 F.3d 938, 944-47 (1st Cir. 1995) (holding that an employee's legal fees incurred in connection with litigation arising out of his employment constitute unreimbursed employee business expenses); Bichl v. Comm'r, 351 F.3d 982, 986-87 (9th Cir. 2003); I.R.C $\$$ 67(a) (limiting miscellaneous itemized deductions to the extent they exceed $2 \%$ of adjusted gross income); I.R.C $\S 56(\mathrm{~b})(1)(\mathrm{A})$ (disallowing miscellaneous itemized deductions under the AMT).

${ }^{108}$ See I.R.C. \$ 62(a) (allowing deductions to gross income).

${ }^{109}$ See Biehl v. Comm'r, 118 T.C. 467, 488 (2002), aff'd, 351 F.3d 982 (9th Cir. 2003) ("We conclude in this case, as we have in prior cases, that it is the job of Congress, if it should decide in its wisdom to do so, to cure the injustice."); Deborah A. Geier, Some Meandering Thoughts on Plaintiffs and Their Attorneys' Fees and Costs, 88 TAX Notes 531, 549 (2000) ("Congress should act now ... to fix the problemand do so retroactively for all open tax years."); NAT'L TAXPAYER ADVOC., 2002 ANNUAL REPORT TO CONGRESS, 167-69, https://www.irs.gov/pub/tas/nta_2002_annual_rpt.pdf [https://perma.cc/T3MY-2RKQ]. ${ }^{110}$ Alexander, 72 F.3d at 946.

111 Press Release, Sen. Charles E. Grassley, Grassley Works to End Unfair Taxation in Civil Rights Cases (May 12, 2003), https://www.grassley.senate.gov/news/news-releases/grassley-works-end-unfairtaxation-civil-rights-cases [https://perma.cc/AN76-PDRW].

${ }^{112} \mathrm{Id}$.

113 See I.R.C $\$$ 62(a)(20), (e)(18) (classifying deductions for legal fees and costs attributable to civil rights and employment claims as above-the-line deductions).

114 See I.R.C $\$ 67(\mathrm{~g})$ (disallowing miscellaneous itemized deductions until 2026). 
C. Does the Form of Attorney Fee Payment Matter?

In a typical situation, a settling defendant will write a check or send a wire payment to the plaintiff's attorney's trust fund account. The plaintiff's attorney will then retain the portion of the settlement to which the attorney is entitled under the contingent fee agreement (i.e., reimbursement of advanced expenses plus the contingent fee amount) and remit the remaining "net settlement" amount to the client.

For example, if the parties settle a case for $\$ 1,000,000$, the defendant typically wires that amount to the plaintiff's attorney's trust fund account. If, under a contingent fee agreement, the attorney is entitled to $\$ 400,000$ for attorney's fees and advanced expenses, the attorney retains that amount and remits $\$ 600,000$ through a wire payment to the plaintiff. In such a case, what are the tax consequences to the plaintiff, assuming the settlement is taxable? There are two possibilities. The plaintiff could include the full $\$ 1,000,000$ gross settlement amount in her gross income and then (to the extent allowed) claim a deduction for the $\$ 400,000$ attorney fee payment. Alternatively, the plaintiff could include only the $\$ 600,000$ net settlement amount. If the $\$ 400,000$ attorney fee deduction in the first scenario is an above-the-line deduction, the end result to the plaintiff would be the same in either case. But where the attorney fee deduction is limited or eliminated; the plaintiff would prefer the $\$ 600,000$ inclusion approach

This issue reached the United States Supreme Court in 2004 in Commissioner v. Banks. ${ }^{115}$ There the Court held that, because the plaintiff used a portion of the settlement to satisfy her liability for attorney's fees under the contingent fee agreement, the entire gross settlement must be included in her gross income. ${ }^{116}$ Under this reasoning, the form of the attorney's fees payment does not matter. ${ }^{117}$ Even if the defendant were to write two checks - one to the attorney for $\$ 400,000$ and another to the plaintiff for $\$ 600,000$ - the result would be the same: the plaintiff must include $\$ 1,000,000$ in gross income and then may, depending on the relevant tax rules relating to deductions, claim a deduction for $\$ 400,000 .^{118}$

The rules that govern the defendant's tax reporting obligations are consistent with this approach. They provide that regardless of whether the defendant sends one check to the attorney or two checks (one to the attorney and the other to the plaintiff), the defendant must report the full settlement amount on a Form 1099-MISC delivered to the plaintiff. ${ }^{119}$

While Banks undoubtedly resolved the main issue regarding the characterization of attorney fee payments under a contingent fee agreement, it arguably left some tangential issues unresolved. For instance, what if the defendant is required to pay the plaintiff's reasonable attorney's fees pursuant to a fee-shifting statute, civil procedure rule, or contractual provision? ${ }^{120}$ Some commentators have argued that because the facts in the

115 Comm'r v. Banks, 543 U.S. 426, 430 (2005).

${ }^{116} \mathrm{Id}$. at 437; see also Polsky, supra note 71, at 133-35 (describing the Banks rule).

117 Polsky, supra note 71, at 133-34.

${ }^{118} \mathrm{Id}$.

119 See Treas. Reg. $\$ 1.6045-5(f)$, Ex. (3). If the settlement is nontaxable because, for example, it represents compensatory damages (other than interest and previously deducted medical expenses) arising out of a personal physical injury, then no Form 1099-MISC reporting is required with respect to the plaintiff. See Treas. Reg. $§ 1.6045-5$ (f), Ex. (2).

${ }^{120}$ Fee-shifting provisions would generally increase settlement amounts because the defendant would be required to pay the plaintiff's attorney's fees if the plaintiff were to prevail at trial. 
Banks case (and its companion, Banaitis ${ }^{121}$ ) did not involve any fee-shifting, the issue remains open. ${ }^{122}$ They contend therefore that a plaintiff might be able to successfully argue that an amount paid directly to the attorney should not be included in her gross income. ${ }^{123}$ However, the IRS in informal guidance has indicated that it disagrees with this view. ${ }^{124}$ Furthermore, a pre-Banks Ninth Circuit case held that a plaintiff was required to include the full gross settlement in gross income even though the underlying claim was based on a federal statute that allowed for fee-shifting, relying on reasoning consistent with that subsequently used in Banks. ${ }^{125}$

\section{Federal Comprehensive Legislative Solution}

As previously discussed, in 2004 Congress recognized the unfairness of the tax trap and eliminated it for many of the types of claims to which it applied. ${ }^{126}$ Civil rights and employment claimants were granted above-the-line deductions for their contingent attorney fees. ${ }^{127}$ Other claims, however, slipped through the cracks, presumably inadvertently. A comprehensive legislative solution would have been to allow above-theline deductions for all otherwise deductible attorney's fees and costs incurred in connection with a claim for damages. Instead of such a global solution, Congress enacted sections 62(a)(20) and 62(e), which provide above-the-line status to a laundry list of specific types of causes of actions. ${ }^{128}$

The legislative history of the 2004 reform explains how the laundry list approach came to be. A 2003 House bill had proposed to solve the tax trap by excluding from gross income all damages received on account of certain civil rights claims even though the claimant did not suffer a personal physical injury. ${ }^{129}$ While this proposal would have solved the tax trap for these claimants, it also would have gone much further by allowing the net settlement to be received tax-free. ${ }^{130}$ Thus, under the 2003 bill, a plaintiff who settled a non-physical civil rights claim for $\$ 1,000,000$ and paid her attorney $\$ 400,000$ would pay zero tax despite receiving a net settlement of $\$ 600,000$.

While the 2003 House bill was never enacted, later Senate bills used the 2003 House bill as a starting point for amending the Code to allow specified claimants abovethe-line deductions for legal costs. ${ }^{131}$ These Senate bills added garden-variety employment claims (i.e., those not based on alleged discrimination or retaliation ${ }^{132}$ ) to the list and

\footnotetext{
${ }^{121}$ Banaitis v. Comm'r, 340 F.3d 1074 (9th Cir. 2003), rev'd on other grounds sub nom. Banks, 543 U.S. at 439

122 See Joanna Laine, Consumer Protection and Tax Law: How the Tax Treatment of Attorney's Fees Undermines the Fair Debt Collection Practices Act, 40 N.Y.U. Rev. L. \& SoC. Change 721, 737 (2016).

${ }^{123} \mathrm{Id}$.

${ }^{124}$ P.M.T.A. 2009-035 (Oct. 22, 2008).

125 Sinyard v. Comm'r, 268 F.3d 756, 758-59 (9th Cir. 2001). For further discussion of the feeshifting/Sinyard interaction, see Gregg D. Polsky \& Stephen F. Befort, Employment Discrimination Remedies and Tax Gross Ups, 90 IowA L. REV. 67, 88-90 (2004).

126 See supra note 113 and accompanying text.

${ }^{127}$ I.R.C $\$ 62(a)(20),($ e)(18) (allowing deductions for civil rights and employment claims to gross income)

${ }^{128} \mathrm{Id}$.

${ }^{129}$ Civil Rights Tax Relief Act of 2003, H.R. 1155, 108th Cong. (2003). The House bill was also simultaneously introduced in the Senate. Civil Rights Tax Relief Act of 2003, S. 557, 108th Cong. (2003).

${ }^{130} \mathrm{Id}$.

${ }^{131}$ Jobs and Growth Tax Relief Reconciliation Act of 2003, S. 1054, 108th Cong. $\$ 521$ (2003); Jumpstart Our Business Strength (JOBS) Act, S. 1637, 108th Cong. $\$ 643$ (2004); American Jobs Creation Act of 2004, Pub. L. No. 108-357, § 703, 118 Stat. 1418, 1546-48 (2004).

${ }^{132}$ Discrimination and retaliation claims were on the original list. See H.R. $1155 \S 140(\mathrm{~b})(18)$.
} 
changed the "remedy" from full exclusion of the settlement to allowance of an above-theline deduction. ${ }^{133}$ There is no evidence that legislators were aware that some remaining claims slipped through the cracks and were therefore still subject to the contingent fee tax trap.

The solution to this problem is simple. Instead of the unwieldly and noncomprehensive list of claims in section 62(e), Congress should enact a provision that confers above-the-line status on all allowable deductions attributable to claims for taxable damages.

\section{E. A Limited State Legislative Solution}

Prior to the Banks decision, some states considered amending their attorney lien laws in an attempt to bolster plaintiffs' claims that the attorney fee portion of a settlement was excluded from gross income. ${ }^{134}$ The reasoning of Banks foreclosed this strategy. ${ }^{135}$ Nevertheless, there remains a limited opportunity for states to pass legislation that would offer some tax relief to plaintiffs who recover punitive damages. Recall that, while punitive damages are included in gross income even in personal physical injury claims, ${ }^{136}$ the attorney's fees allocable to those punitive damages are often characterized as miscellaneous itemized deductions and therefore are disallowed under current law. ${ }^{137}$

For instance, assume that a plaintiff with a personal physical injury claim receives a $\$ 1,000,000$ settlement, half of which is allocable to pain and suffering and half of which is allocable to punitive damages. Her attorney is entitled to a $\$ 400,000$ contingent fee. The punitive damages of $\$ 500,000$ are included in her gross income, while the $\$ 500,000$ for pain and suffering is excluded. Because half of the settlement is taxed, half of the contingent fee would potentially be deductible as a miscellaneous itemized deduction. ${ }^{138}$ Under current law, however, miscellaneous itemized deductions are disallowed. ${ }^{139}$ Therefore, the plaintiff would end up paying tax on the entire $\$ 500,000$ punitive damages portion of the settlement, unreduced by any part of the contingent attorney's fees.

${ }^{133}$ S. $1054 \S 521 ;$ S. $1637 \S 703 ; \S 703,118$ Stat. at $1546-48$.

134 See Stephen D. Feldman, Comment, Exclusion of Contingent Attorneys' Fees from Gross Income, 68 U. CHI. L. REV. 1309, 1317-19 (2001). Prior to Banks, some circuit courts had determined that state attorney lien laws had effectively transferred the attorney fee portion of the claim and, therefore, the plaintiff was required to include only the net settlement in gross income. Other circuit courts had rejected that reasoning. See id.

${ }^{135}$ Comm'rv. Banks, 543 U.S. 426, 437 (2005) (“Th[e] rule [that plaintiffs must include the attorney fee portion of a recovery in gross income] applies whether or not the attorney -client contract or state law confers any special rights or protections on the attorney, so long as these protections do not alter the fundamental principal-agent character of the relationship ... State laws vary with respect to the strength of an attorney's security interest in a contingent fee and the remedies available to an attomey should the client discharge or attempt to defraud the attomey. No state laws of which we are aware, however, even those that purport to give attorneys an 'ownership' interest in their fees . . . convert the attorney from an agent to a partner.").

${ }^{136}$ See supra note 31 and accompanying text.

137 See $\$ 67(\mathrm{~g})$ (disallowing miscellaneous itemized deductions until 2026). Attorney's fees attributable to punitive damages should constitute above-line-deductions where the underlying claim arises out of the plaintiff's trade or business. See I.R.C. $\S 62(\mathrm{a})(1)$. In addition, attomey's fees attributable to punitive damages should constitute above-the-line deductions where the claim arises out of civil rights or employment claims described in section 62(e) because of the broad "in connection with" language used in section 62(a)(20).

${ }^{138}$ The other half is flatly non-deductible because it is attributable to the tax-exempt recovery. See I.R.C. $\S 265$ (a)(1). Allowing such a deduction would illogically give the taxpayer a double tax benefit: first, the $\$ 500,000$ pain and suffering award would not be taxed and, second, the $\$ 200,000$ attorney's fee attributable to the award could be used to shelter gross income from other sources (such as wages).

${ }^{139}$ See I.R.C $\$ 67(\mathrm{~g})$ (disallowing miscellaneous itemized deductions until 2026). 
States that have a split-recovery regime for punitive damages could amend their split-recovery statute to ameliorate this problem. In a split-recovery regime, a certain percentage of any punitive damages award is remitted directly to the state in which the claim is brought. ${ }^{140}$ In a 2002 Chief Counsel Advice Memorandum (the "2002 C.C.A."), the IRS determined that a plaintiff is not required to include the state's portion in her gross income because the transfer to the state occurs by operation of law and therefore the plaintiff has "no command over the disposition" of that amount. ${ }^{141}$ In contrast, the transfer of the attorney's fee portion is the result of the contingent fee agreement, which was voluntarily executed by the plaintiff.

To illustrate, assume that, in the example above, $50 \%$ of the net punitive damages award (i.e., net of attorney's fees attributable to the punitive damages award) must be remitted to the state. The $\$ 1,000,000$ settlement would be distributed as follows:

$\$ 450,000$ to the plaintiff $(\$ 300,000$ net compensatory amount plus

$\$ 150,000$ net punitive amount).

$\$ 400,000$ to the attorney $(40 \%$ of $\$ 1,000,000$ settlement)

$\$ 150,000$ to the state $(50 \%$ of $(\$ 500,000$ punitive damages less $\$ 200,000$

attorney's fee)).

The plaintiff would be able to exclude from her gross income the $\$ 500,000$ of the settlement that represents compensatory damages. In addition, under the 2002 C.C.A., the plaintiff would also exclude the $\$ 150,000$ that was remitted to the state. ${ }^{142}$ Only the remaining $\$ 350,000$ would be included in gross income. ${ }^{143}$

The reasoning of the 2002 C.C.A. provides a potential avenue to ameliorate the contingent fee tax trap in punitive damages cases. States with split-recovery regimes could amend the existing distribution rules to provide for an automatic payment to the attorney. A recent legislative proposal in Oregon is illustrative. ${ }^{144}$ Under current Oregon law, $70 \%$ of the gross punitive damages award is paid to the state. ${ }^{145}$ The remaining $30 \%$ is paid to the plaintiff. ${ }^{146}$ The plaintiff's attorney's fee is paid out of the plaintiff's $30 \%$ award, but cannot exceed $20 \%$ of the gross award. ${ }^{147}$ Thus, in the event of a $\$ 1,000,000$ punitive damages award and a contingent fee percentage of $20 \%$ or greater, $\$ 700,000$ would go to the state, $\$ 100,000$ to the plaintiff, and $\$ 200,000$ to the attorney. For federal income tax purposes, the plaintiff would include $\$ 300,000$ in gross income and receive no deductions because of the disallowance of miscellaneous itemized deductions under current law. If the plaintiff's marginal tax rate is $33 \%$, the plaintiff would end up with no punitive damages award on an after-tax basis.

${ }^{140}$ See, e.g., OR. REV. STAT. $§ 31.735$ (2020).

${ }^{141}$ C.C.A. 2002-46-003 4 (Aug. 1, 2002).

${ }^{142} \mathrm{Id}$.

143 The 2002 C.C.A. also determined that the taxpayer could claim a deduction for the attorney fee portion of the award that was attributable to the state's portion of the recovery. Therefore, the plaintiff could claim a deduction for the full $\$ 200,000$ attorney fee attributable to punitive damages. $I d$. at $4-5$. This deduction, however, would constitute a miscellaneous itemized deduction and would therefore, under current law, be disallowed. I.R.C. $\$ 67(\mathrm{~g})$. At the time of the C.C.A.'s publication, miscellaneous itemized deductions were deductible to the extent they exceeded $2 \%$ of adjusted gross income and were disallowed entirely for AMT purposes. I.R.C. $\S 62(a) ;$ I.R.C. $\$ 56(b)(1)(A)(i)$.

${ }^{144}$ S. 874, 80th Leg. Assemb., Reg. Sess. (Or. 2019).

${ }^{145}$ OR. REV. STAT. $\$ 31.735(1)$ (a).

${ }^{146} I d$.

${ }^{147} I d$. 
Oregon Senate Bill 874 would substantially alter this regime. ${ }^{148}$ Any punitive damages recovery would first repay costs incurred in the recovery of punitive damages, such as court costs and expert witness fees. ${ }^{149}$ The remaining amount would be divided equally (one-third each) to the plaintiff, the plaintiff's attorney, and the state. ${ }^{150}$ If $\$ 1,000,000$ is recovered as punitive damages (assuming no costs), approximately $\$ 333,333$ would go to each. For federal income tax purposes, under the reasoning in the 2002 C.C.A., the plaintiff would be required to include only her $\$ 333,333$ share in gross income because the transfer of the remaining amount occurs by operation of law and therefore she has no command over its disposition. ${ }^{151}$ The following Table 3 contrasts the results under current law and under Oregon Senate Bill 874, assuming the plaintiff is subject to a marginal tax rate of $33 \%$ :

Table 3

\begin{tabular}{|l|c|c|c|c|c|}
\hline Approach & $\begin{array}{c}\text { Gross } \\
\text { Settlement }\end{array}$ & $\begin{array}{c}\text { State's } \\
\text { Share }\end{array}$ & $\begin{array}{c}\text { Attorney's } \\
\text { Share }\end{array}$ & $\begin{array}{c}\text { Plaintiff's } \\
\text { Share (pre- } \\
\text { tax) }\end{array}$ & $\begin{array}{c}\text { Plaintiff's } \\
\text { Share (after- } \\
\text { tax) }\end{array}$ \\
\hline $\begin{array}{l}\text { Current } \\
\text { Law }\end{array}$ & $\$ 1,000,000$ & $\$ 700,000$ & $\$ 200,000$ & $\$ 100,000$ & $\$ 0$ \\
\hline Or. S. 874 & $\$ 1,000,000$ & $\$ 333,333$ & $\$ 333,333$ & $\$ 333,333$ & $\$ 222,222$ \\
\hline
\end{tabular}

\section{F. Administrative Solutions}

Recognizing the patent unfairness of the tax trap, the federal government could provide some relief to affected plaintiffs through administrative action. As discussed below, plaintiffs can make a nonfrivolous argument that contingent fees represent capital expenditures rather than potentially deductible expenses. Because capital expenditures increase a plaintiff's tax basis in her claim, they offset the gross settlement amount in arriving at gross income. If a contingent fee of $\$ 400,000$ (out of a $\$ 1,000,000$ total settlement amount) is capitalized, a plaintiff would be required to include only the net $\$ 600,000$ in her gross income. This is the same end result as including the full $\$ 1,000,000$ in gross income but allowing an above-the-line deduction for the $\$ 400,000$ contingent fee.

While the Banks court explicitly declined to address the capitalization approach because it was not raised in the lower courts, it has garnered the support of some prominent

148 OR. S. 874

${ }^{149} \mathrm{Id}$.

${ }^{150} I d$.

${ }^{151}$ C.C.A. 2002-46-003 4 (Aug. 1, 2002). It could be argued that the mere act of hiring an attorney under the revised Oregon split recovery regime provides the plaintiff with sufficient "command over the disposition" over the attorney fee portion to require inclusion in the plaintiff's gross income. To ameliorate this concem, the state law could additionally provide that, if the plaintiff was not represented by an attomey, the portion of the proceeds that otherwise would have gone to the attorney would instead be remitted in full to the state. Thus, in the example, if the plaintiff was pro se, the state's share would be increased from $\$ 333,333$ to $\$ 666,667$, while the plaintiff's share would remain $\$ 333,333$. This would ensure that regardless of whether the plaintiff retained an attorney, her share would always be limited to one-third of the punitive damages. This would effectively forestall any IRS argument that the plaintiff retained any "command over the disposition" of the attomey fee portion of the recovery. 
commentators. ${ }^{152}$ While some language in the regulations and a few cases are problematic, they would not prevent the Treasury or the IRS from promulgating a rule that would protect affected plaintiffs. ${ }^{153}$ For instance, the IRS could issue a Revenue Procedure stating that the IRS will not challenge a taxpayer who takes the position that a contingent fee is capitalized. The IRS has used a similar approach in other situations to provide taxpayer relief and certainty. ${ }^{154}$ It would make sense to do so here as well.

\section{G. Taxpayer Arguments}

While the Banks decision forecloses the most straightforward legal argument to avoid the contingent fee tax trap, other arguments are potentially still available. One set of arguments involves those that the Banks case explicitly declined to consider because they were not raised in the lower courts. Another set of arguments relates to an expansive interpretation of the 2004 amendment that applies to employment and civil rights claims.

In the Banks case, the Court expressly declined to comment on three arguments that had not been advanced in earlier stages of the litigation. ${ }^{155}$ One argument was relevant only to employment-related claimants, which are no longer subject to the tax trap. ${ }^{156}$ Another argument was that the contingent fee arrangement constitutes a partnership for tax purposes. ${ }^{157}$ While the Court stated that it was declining to comment on this argument, it had earlier in the opinion "reject[ed] the suggestion to treat the attorney-client relationship as a sort of business partnership or joint venture for tax purposes." 158 Thus, as Professor Brant Hellwig explained, "far from declining comment on the taxpayers' [partnership for tax purposes] argument, it appears that the Court had already expressly rejected it." 159

While these two arguments would not be helpful to affected claimants, the third and final theory is still potentially viable: Under that theory, a plaintiff in a contingent fee arrangement could avoid the tax trap by capitalizing the attorney's fees and adding it to her tax basis in the claim (which, before such adjustment, was zero). This capitalization theory was discussed above, in the recommendation that the IRS issue a safe harbor for this approach (but not requiring it for all litigation fees). The theory is difficult (though

152 See Comm'r v. Banks, 543 U.S. 426, 437-38 (2005); Joseph M. Dodge, The Netting of Costs Against Income Receipts (Including Damage Recoveries) Produced by Such Costs, Without Barring Congress from Disallowing Such Costs, 27 VA. TAX. REV. 297, 334-38 (2007); Charles Davenport, Why Tort Legal Fees Are Not Deductible, 97 TAX Notes 703, 704 (2002); Deborah A. Geier, Attorney's Fees: Davenport Has the Right Idea, 97 TAX NotEs 1627, 1629 (2002).

153 See Hellwig \& Polsky, supra note 106, at 917-21 (explaining the difficulty in reconciling the capitalization approach with Treas. Reg. $\$ 1.212-1(\mathrm{k})$ and several court decisions).

154 See, e.g., Rev. Proc. 93-27, 1993-2 C.B. 343 (providing the circumstances in which the IRS will not challenge the claimed tax-free treatment upon receipt of a partnership profits interest).

${ }^{155}$ Banks, 543 U.S. at 437-38.

${ }^{156}$ See Brief for Professor Stephen B. Cohen as Amicus Curiae at 10-14, Comm'r v. Banks, 543 U.S. 426 (2005) (Nos. 03-892 \& 03-907) (arguing that contingent fees in employment-related litigation constitute reimbursed employee business expenses, which are deductible above-the-line under I.R.C. $\S 62(\mathrm{a})(2)(\mathrm{A}))$; I.R.C. $\S 62(\mathrm{a})(20)$, (e)(18)(ii) (allowing above-the-line deductions for employment-related legal fees).

${ }^{157}$ Banks, 543 U.S. at 435-36.

${ }^{158} \mathrm{Id}$. at $436-38$.

${ }^{159}$ Brant J. Hellwig, The Supreme Court's Casual Use of the Assignment of Income Doctrine, 2006 U. ILL. L. REv. 751, 761 (2006). Even if the partnership for tax purposes theory were viable, it is far from clear whether, due to the technicalities of partnership tax rules, the argument would have even helped the taxpayer avoid the contingent fee tax trap. For a discussion of such technical issues, see Hellwig \& Polsky, supra note 106 , at $913-15$. 
arguably not impossible) to square with existing legal authorities, yet it is conceptually sound, and has the support of several esteemed commentators. ${ }^{160}$

Because it is a nonfrivolous position, affected plaintiffs could legally take the capitalization position on their federal income tax returns. However, plaintiffs would need to keep in mind the potential tax penalties if the IRS were to successfully challenge the position. ${ }^{161}$ Yet, such a penalty could be avoided if the position is adequately disclosed on the tax return. ${ }^{162}$ Taxpayers often prefer to avoid disclosure of a tax position because it is viewed as a "red flag" to the IRS, beckoning them to audit the position. But, in this context, disclosure would likely not be a red flag because defendants are required to report the gross settlement amount (i.e., the settlement amount unreduced by the contingent attorney fee) to the plaintiff on a Form 1099-MISC, regardless of whether one or two checks are issued. ${ }^{163}$ If a plaintiff takes the capitalization tax position and includes only her net settlement in gross income, there will be a discrepancy between gross income and the Form 1099-MISC. Accordingly, a red flag would seemingly exist regardless of whether adequate disclosure was made.

Another potential legal argument relates to the definition of "civil rights" in section 62(e)(18)(i). Recall that in 2004 Congress amended the Code to allow a new above-theline deduction for legal fees paid by certain claimants. ${ }^{164}$ Section 62(e) provides a lengthy list of covered claims. Paragraphs (1) through (16) list claims allowed under specific federal statutes ${ }^{165}$ paragraph (17) describes employee whistleblower claims under federal law; ${ }^{166}$ and paragraph (18) contains two subparagraphs, both of which apply to claims based on federal, state, or local law, whether statutory or common law, the first of which applies to claims based on law "providing for the enforcement of civil rights" 167 and the second of which applies to claims based on law "regulating any aspect of the employment relationship, including claims for wages, compensation, or benefits." 168

Paragraph (18) is a catchall category. It seems to make all of the prior 17 paragraphs redundant, as they all appear to apply to civil rights or employment-related claims. One issue is the scope of the term "civil rights" in section 62(e)(18)(i). Robert Wood, a prominent commentator on tax issues arising out of litigation, has argued for an extremely expansive interpretation of the term as a means of solving the contingent fee tax

${ }^{160}$ Dodge, supra note 152, at 334-38; Davenport, supra note 152, at 704; Geier, supra note 152 , at 3. But see Hellwig \& Polsky, supra note 106 , at $915,921$.

${ }^{161}$ In general, to avoid tax penalties for a large improper and undisclosed tax position, the position must be supported by "substantial authority." I.R.C. $\$ 6662(\mathrm{~d})(2)(\mathrm{B})(\mathrm{i})$. If the position is adequately disclosed on the tax return, then the position need only be supported by a "reasonable basis." I.R.C. $\S 6662$ (d)(2)(B)(ii). The substantial authority standard is "more stringent that the reasonable basis standard," Treas. Reg. § 1.6662$4(d)(2)$, which itself is "significantly higher than not frivolous or not patently improper," Treas. Reg. § 1.6662$3(\mathrm{~b})(3)$.

${ }^{162}$ I.R.C. $\S 6662$ (d)(2)(B)(ii)(I) (providing an exception to substantial understatement penalties for tax positions that are adequately disclosed on the tax return). In addition to adequate disclosure, this exemption from penalties requires the taxpayer's position to be supported by a reasonable basis. I.R.C. $\S 6662(\mathrm{~d})(2)(\mathrm{B})(\mathrm{ii})(\mathrm{II})$.

163 See Treas. Reg. \& 1.6045-5(f), Ex. (1), (3).

164 See supra note 113 and accompanying text.

165 I.R.C. $\$ 62(\mathrm{e})(1)-(16)$.

${ }^{166}$ I.R.C. $\$ 62(\mathrm{e})(17)$.

${ }^{167}$ I.R.C. $\S 62(\mathrm{e})(18)(\mathrm{i})$.

${ }^{168}$ I.R.C. $\$ 62(\mathrm{e})(18)(\mathrm{ii})$ 
trap. ${ }^{169}$ Wood notes that Black's Law Dictionary defines the term "civil rights" as rights guaranteed by the Constitution or anti-discrimination legislation and that the IRS, in informal guidance in another context, applied a similar interpretation. ${ }^{170}$ Wood seems to acknowledge that this is the common definition of the term "civil rights." also explains that courts have used different interpretations, some consistent with the Black's Law Dictionary definition but others applying a much broader interpretation. ${ }^{172}$ Under the broader interpretation, civil rights claims would include all civil claims for redress. If this view were to prevail, the contingent fee tax trap would be eliminated, because all claims for damages (even punitive damages claims) would constitute civil rights claims and, accordingly, the corresponding legal fees would be above-the-line deductions.

The statutory interpretation inquiry which necessarily follows is whether Congress intended a narrow, common interpretation or an expansive one. While neither the IRS nor federal courts have considered this issue, it has arisen in a Massachusetts state tax case. ${ }^{173}$ There the taxpayer was a defamation plaintiff who argued that his contingent attorney's fee was excluded from gross income for Massachusetts income tax purposes, which apparently largely depended on whether the fee was deductible on an above-the-line basis for federal income tax purposes. ${ }^{174}$ The Massachusetts Appellate Tax Board summarily concluded that a garden-variety defamation claim did not constitute a civil rights claim. ${ }^{175}$

Given the absence of federal authority on the issue, the IRS or a reviewing court would consider the interpretation on a clean slate. While Wood makes an admirable effort in arguing for the expansive interpretation, ${ }^{176}$ he does not adequately address two significant obstacles. First, if Congress had intended to grant an above-the-line deduction for legal fees incurred in connection with all claims for damages, it could have easily and simply said so. In fact, it could have enacted the simple legislative reform recommended above. ${ }^{177}$ Instead, Congress drafted a very lengthy and specific eighteen-paragraph list of covered claims. Why go through all this trouble if the intent was for universal application to all legal claims? Giving "civil rights" its common, more narrow usage avoids this inexplicableness.

Wood responds to this point by noting that, even with a narrow interpretation, section $62(\mathrm{e})$ still has unnecessary surplusage. ${ }^{178}$ As a factual matter, this is true. The list of federal claims in paragraphs (1) through (16) appears redundant with statutory-based federal "civil rights" claims, as Wood notes. ${ }^{179}$ But the legislative history explains how this occurred. Recall that the statutory language in question arose out of an earlier bill,

${ }^{169}$ Robert W. Wood, Civil Rights Fee Deduction Cuts Tax on Settlements, 166 TAX NOTES FED. 1481 , $1482-83(2020)$.

${ }^{170} \mathrm{Id}$.

${ }^{171} I d$. at 1483 (noting that this interpretation "may be the more common" definition, compared with the extremely expansive interpretation described below).

${ }^{172} \mathrm{Id}$. at $1482-83$

${ }^{173}$ Chighisola v. Comm'r, No. C319142, ATB 2016-384 (Mass. App. Tax Bd. Sept. 26, 2016) https://archives.lib. state. ma.us/bitstream/handle/2452/430343/ocn960972221.pdf?sequence=1\&isAllowed=y [https://perma.cc/Q5K9-HA87].

${ }^{174} \mathrm{Id}$. at 391-92.

${ }^{175} \mathrm{Id}$. at 392 ("Here, there was no indication in the record that the settlement at issue arose from a claim involving the enforcement of civil rights.").

176 Wood, supra note 169 , at 1483 .

177 See supra Part III.D.

${ }^{178}$ Wood, supra note 169 , at 1487 .

179 See id. 
titled the Civil Rights Tax Relief Act of 2003, that would have excluded all damages from gross income, instead of merely allowing an above-the-line deduction for attorney's fees. ${ }^{180}$ The earlier bill used the same 18-paragraph format, as well as the nearly identical relevant language: "any provision of State or local law, or common law claims permitted under Federal, State, or local law, providing for the enforcement of civil rights ..."181 The enacted language includes the term "Federal" in the introductory language: "[a]ny provision of Federal, State, or local law ...."182 In light of this overlap in language, it seems quite likely that "Federal" was included just in case the listed federal statutes in paragraphs (1) through (16) were unintentionally not fully comprehensive. ${ }^{183}$ Thus, while the provision is no model of elegant statutory drafting, its legislative history explains the surplusage that Wood identifies.

Second, Wood's proffered interpretation is difficult to square with the origins of the relevant language. The Civil Rights Tax Relief Act of 2003 used language identical in all relevant respects to that in the enacted section 62(e)(18)(i), expressly encompassing any provisions "providing for the enforcement of civil rights." 184 The 2003 bill would have excluded from gross income all recoveries with respect to its listed claims. ${ }^{185}$ Wholesale exclusion of damages from gross income would have been a radical change to the traditional tax treatment of litigation recoveries. Under existing law, recoveries that are not offset by tax basis are included in gross income except to the extent that section 104(a)(2), which carves out compensatory damages received on account of personal physical injury, applies. ${ }^{186}$ Under Wood's expansive interpretation of "civil rights," the Civil Rights Tax Relief Act of 2003 would have turned this rule completely on its head. It would mean that all damage recoveries would be tax-free, thus rendering section 104(a)(2) obsolete. It is hard to imagine that any of the drafters would have conceived the language of the Civil Rights Tax Relief Act of 2003 as stretching so far.

\section{H. Structuring to Avoid Non-Deductibility}

Banks foreclosed the most intuitive options for avoiding the contingent fee tax trap. Asking the defendant to cut two checks or trying to assign a portion of the claim to the attorney upon execution of the fee agreement will not work. Nor, apparently, will trying to formalize the attorney-client relationship as a partnership for tax purposes.

Yet other less intuitive structuring solutions may still be available. One potential option takes advantage of the prospective elimination of miscellaneous itemized deductions at the end of 2025. ${ }^{187}$ Assuming that Congress does not statutorily extend the section $67(\mathrm{~g})$ elimination, attorney's fees that represent miscellaneous itemized deductions could be pushed out into 2026 and beyond and thereby retain, to some extent, their deductibility. The strategy would also allow more time for Congress, the Treasury, or the IRS to act to solve the problem by amending the Code or promulgating an administrative rule.

Such so-called "attorney fee structures" should accomplish a deferral of the fee deduction by paying out the attorney's fees through an intermediary (a structured

\footnotetext{
${ }^{180}$ Civil Rights Tax Relief Act of 2003, H.R. 1155, 108th Cong. (2003).

${ }^{181} \mathrm{Id}$. at $\S 140(\mathrm{~b})(1)-(18)$.

182 I.R.C. $\S 62(\mathrm{e})(18)$ (emphasis added).

${ }^{183}$ I.R.C. $\S 62(\mathrm{e})(1)-(16),(18)$.

${ }^{184}$ Compare H.R. $1155 \S 140(\mathrm{~b})(18)$ with I.R.C. $\$ 62(\mathrm{e})(18)(\mathrm{i})$.

185 See H.R. 1155 § 140(a).

${ }^{186}$ Polsky, supra note 71 , at $123-24$.

187 See I.R.C. \& $67(\mathrm{~g})$.
} 
settlement company) over time, instead of in a lump sum payment upon settlement of the case. In many cases where attorney fee structures are used, the plaintiff also structures her portion of the settlement. Regardless of whether the plaintiff uses a structured settlement, when attorney's fees are structured, the plaintiff recognizes gross income under Banks from the payment of the fee only at the time the fee is actually received by the attorney and, correspondingly, the plaintiff recognizes a corresponding deduction at the same time (subject to any limitations on the deduction that may apply).

Consider a case where a defamation plaintiff will receive $\$ 70,000$ per year for five years, with the first payment due in 2026. Her attorney likewise structures his fee, so he will receive $\$ 30,000$ per year for five years, with the first payment due in 2026 . Under Banks, the plaintiff should report $\$ 100,000$ in annual gross income in each year beginning in 2026 , as well as a $\$ 30,000$ miscellaneous itemized deduction. ${ }^{188}$ If Congress does not extend the disallowance of miscellaneous itemized deductions, the $\$ 30,000$ deduction will be allowed for regular tax purposes (to the extent it exceeds $2 \%$ of the plaintiff's adjusted gross income), though it will not be allowed for AMT purposes.

Before implementing this strategy, several issues must be considered. First, as noted above, Congress could change the law, for better or for worse. If Congress extends the elimination of miscellaneous itemized deductions, then deferral of those deductions would be useless. If Congress does not act, the elimination will expire. But the 2017 Tax Act has many provisions that are set to expire on December 31, 2025, and undoubtedly some will be extended. On the other hand, the attention on the contingent fee tax trap could cause Congress to simply fix the problem by extending above-the-line treatment (or cause the Treasury or the IRS to fix the problem through rulemaking). In sum, there is no assurance that 2026 will be better for affected plaintiffs than 2020 , though it likely will not be worse.

Second, if miscellaneous itemized deductions return to their pre-2018 status (as current law requires), they would still be subject to a $2 \%$ floor and would still be disallowed for AMT purposes. ${ }^{189}$ Depending on the specific tax characteristics of the plaintiff, the result might not be much better than under the current rule of complete disallowance.

\section{CONCLUSION}

Among its wide-ranging provisions, the 2017 Tax Act included two provisions that significantly affect certain types of personal injury plaintiffs. Section 162(q), while designed with good intentions, unwittingly burdens sexual harassment and sexual abuse victims through taxing the effective sale of an NDA by plaintiffs to defendants. The incidence of the tax will likely be shifted to some extent by defendants to plaintiffs in the form of lower settlement offers. The provision is also extremely ambiguous in many significant aspects. While the Treasury or the IRS will likely resolve at least some of these ambiguities through rulemaking, it is not clear that all of them can be sensibly resolved.

The 2017 Tax Act also eliminated miscellaneous itemized deductions. Although most taxpayers who have these types of deductions do not suffer significant losses due to the elimination, certain personal injury plaintiffs may lose massive deductions for the

188 Because no tax authorities have considered the precise issues, these tax conclusions are not entirely free from doubt. Nevertheless, they logically follow from the Tax Court's analysis of attorney fee structures in Childs $v$. Commissioner and an IRS private letter ruling approving of so-called nonqualified structured settlements. Childs v. Comm'r, 103 T.C. 634, 651-53 (1994), aff'd, 89 F.3d 856 (11th Cir. 1996); P.L.R. 2008-36-019 (June 2, 2008). For further discussion of this issue, see Polsky, supra note 71, at 158-64. ${ }^{189}$ See I.R.C. $\S \S 56(\mathrm{~b})(1)(\mathrm{A})(\mathrm{i}), 67(\mathrm{a})$. 
contingent fees they pay to their lawyers. For some plaintiffs this will cause their federal income tax liability to increase by hundreds of thousands, if not millions, of dollars. There is no tax policy justification whatsoever for this result. Congress should amend the Code to fix this problem. Should such legislative efforts fail, however, the IRS should promulgate the safe harbor rule recommended in this Article, which would adequately resolve the situation. 